The Free Internet Journal

for Organic Chemistry
Review

Arkivoc 2018, part ii, 17-39

\title{
The intermolecular hydro-oxycarbonylation of internal alkynes: current state of the art
}

\author{
Pedro J. González-Liste, Javier Francos, Sergio E. García-Garrido, and Victorio Cadierno*
}

Laboratorio de Compuestos Organometálicos y Catálisis (Unidad Asociada al CSIC), Centro de Innovación en Química Avanzada (ORFEO-CINQA), Departamento de Química Orgánica e Inorgánica, IUQOEM, Facultad de Química, Universidad de Oviedo, Julián Clavería 8, E-33006 Oviedo, Spain

Email: vcm@uniovi.es

\section{Dedicated to Prof. Kenneth Laali on the occasion of his 65th birthday}

Received 05-23-2017

Accepted 08-03-2017

Published on line 10-04-2017

\section{Abstract}

The intermolecular addition of carboxylic acids to alkynes is one of the most straightforward and atomeconomical methods currently available for the preparation of synthetically useful enol esters. However, the vast majority of works have focused on the use of terminal alkynes, substrates much more reactive than their corresponding internal counterparts. In fact, efficient and general protocols for hydro-oxycarbonylation of internal alkynes have only seen the light in recent years. In the present review article an overview of the progress made in the field is given. Catalytic reactions promoted by ruthenium, palladium, silver and gold complexes/salts, along with some specific metal-free protocols, are covered.
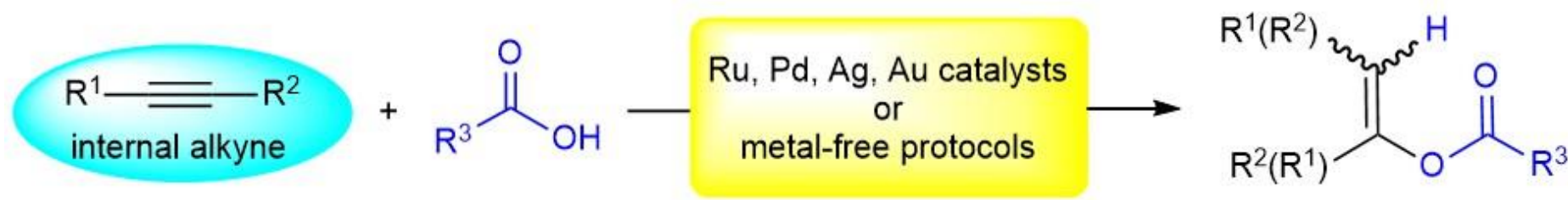

$E / Z$ isomers

Keywords: Enol esters, alkynes, carboxylic acids, catalysis, addition reactions 


\section{Table of Contents}

1. Introduction

2. Metal-Catalyzed Reactions

2.1. Ruthenium-based catalysts

2.2. Palladium-based catalysts

2.3. Silver-based catalysts

2.4. Gold-based catalysts

3. Metal-Free Reactions

4. Conclusions

\section{Introduction}

Enol ester derivatives represent a relevant class of compounds widely used as mild acylating reagents, ${ }^{1-4}$ as monomers for the production of diverse types of polymers and copolymers, ${ }^{5-8}$ and as starting materials in a large variety of reactions, including asymmetric hydrogenation, ${ }^{9-12}$ cycloaddition, ${ }^{13-16}$ cyclization, ${ }^{17-20}$ hydroformylation, ${ }^{21-23}$ cross-coupling, ${ }^{24-27}$ Michael addition, ${ }^{28-31}$ aldol-type, ${ }^{32-34}$ Mannich-type ${ }^{35}$ and amide bond-forming processes, ${ }^{36}$ to name a few. The enol ester motif is also found in a number of natural products with relevant biological properties. ${ }^{37-40}$ Hence, the development of efficient and general methods for their preparation has long attracted the interest of organic chemists. In this regard, the most classical approaches for the synthesis of enol esters involve the $\mathrm{O}$-acylation of enolates ${ }^{41}$ and the acyloxymercuration of alkynes. ${ }^{42}$ However, from a current perspective, these methods are not attractive since they require the use of stoichiometric amounts of strong acids/bases or toxic mercury salts, respectively. In the search for improved synthetic methods, transition metal-catalyzed reactions, such as the isomerization of allylic esters, ${ }^{9}$ the coupling of carboxylate salts or carboxylic acids with potassium alkenyltrifluoroborate salts, ${ }^{43}$ the oxidative esterification of aldehydes or ethers with 1,3-dicarbonyl compounds, ${ }^{44,45}$ the oxidative coupling of alkenes with carboxylic acids, ${ }^{46-48}$ the rearrangement of propargylic esters, ${ }^{49,50}$ the coupling of ketenes with aldehydes, ${ }^{51}$ or the addition of carboxylic acids to alkynes, ${ }^{52-56}$ have emerged in recent years as very effective alternatives. Among them, the transition metal-catalyzed addition of carboxylic acids to alkynes (reaction also referred in the literature as hydro-oxycarbonylation or hydrocarboxylation of alkynes) is the one that has found greater application due to its complete atom economy and substrates availability. Indeed, since the first report by Shvo and Rotem in $1983,{ }^{57}$ a huge number of catalytic systems for this reaction have been reported, most involving late transition metals such as $\mathrm{Ru}, \mathrm{Rh}, \mathrm{Ir}, \mathrm{Re}, \mathrm{Pd}, \mathrm{Au}$ or Ag. ${ }^{52-56}$ In particular, the intermolecular addition of carboxylic acids to terminal alkynes has been widely studied with these metals and different catalysts capable of controlling the regioselectivity (Markovnikov and anti-Markovnikov products), and in some cases the stereoselectivity, of the addition process are currently known (Scheme 1). ${ }^{52-56}$

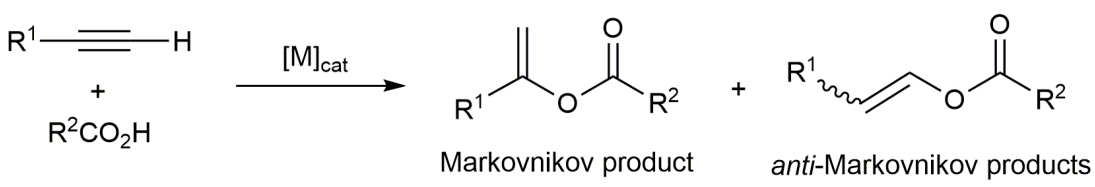

Scheme 1. The metal-catalyzed hydro-oxycarbonylation of terminal alkynes. 
In contrast, the use of internal alkynes in intermolecular hydro-oxycarbonylation reactions has been comparatively much less reported. Indeed, most of the metal catalysts active with terminal alkynes have shown to be completely ineffective with the internal ones, and those that work usually present a reduced substrate scope or require of higher catalyst loadings, reaction times or temperatures. ${ }^{52-56}$ Obviously, the lower reactivity of internal vs terminal alkynes is due to the greater steric hindrance of the former, which disfavour their coordination to the metal. A similar trend has also been observed in the intramolecular version of the process, i.e. the cycloisomerization of alkynoic acids. ${ }^{58-63}$ However, we would like to stress that these intramolecular reactions are favoured from a thermodynamic point of view and do not represent a notable synthetic problem. ${ }^{52,64}$ Another challenging aspect related with the use of internal alkynes concerns the control of the regio- and stereoselectivity of the addition process since, starting from non-symmetrically substituted substrates $R^{1} C \equiv C R^{2}\left(R^{1} \neq R^{2}\right)$, up to four isomeric enol esters can be formed (obviously difficult to separate). In spite of all these difficulties, some efficient, selective and general protocols for the hydrooxycarbonylation of internal alkynes have seen the light in recent years. The aim of the present review article is to provide an overview on the developments achieved in this field.

\section{Metal-Catalyzed Reactions}

\subsection{Ruthenium-based catalysts}

Among the different metal sources employed to promote the addition of carboxylic acids to alkynes, ruthenium catalysts have been the most widely studied, due to their high efficiency and tolerance to functional groups. ${ }^{52-56,65,66}$ However, the vast majority are only effective with terminal alkynes, and only a limited number of examples active in the hydro-oxycarbonylation of internal acetylenic substrates can be found in the literature. In this context, in their pioneering works, Rotem and Shvo studied the addition of different carboxylic acids to diphenylacetylene, 4-octyne and DMAD (dimethyl acetylenedicarboxylate) using $\left[\mathrm{Ru}_{3}(\mathrm{CO})_{12}\right](2 \mathrm{~mol} \%)$ as catalyst (Scheme 2). ${ }^{57,67}$ As expected, the reactions, which were performed in toluene at $145{ }^{\circ} \mathrm{C}$, proceeded at comparatively much lower rates than those encountered when employing terminal alkynes as substrates. Concerning the reactions outcome, starting from 4-octyne and DMAD the enol esters 1 were obtained stereoselectively as a result of the syn-addition of the carboxylic acid to the $\mathrm{C} \equiv \mathrm{C}$ bond. In contrast, starting from diphenylacetylene, the corresponding enol esters $\mathbf{2}$ were generated as mixtures of $E / Z$ isomers. In addition, minor amounts of the rearranged products $\mathbf{3}$ were also formed in these reactions. The authors suggested that, similarly to the cases of 4-octyne and DMAD, syn-addition of the carboxylic acid to $\mathrm{PhC} \equiv \mathrm{CPh}$ initially takes place to generate the kinetically controlled $(E)-\mathbf{2}$ products, which further isomerize into the thermodynamically more stable $Z$ ones under the thermal conditions employed. The reactivity of benzoic acid towards Ph-C $\equiv$ C-nPent was also briefly explored by Rotem and Shvo, leading under identical reaction conditions to a complex mixture of products, as a result of a non regio- and stereoselective addition of the acid to the unsymmetrically substituted $\mathrm{C} \equiv \mathrm{C}$ bond (rearranged products related to $\mathbf{3}$ were also observed).

More recently, $\left[\mathrm{Ru}_{3}(\mathrm{CO})_{12}\right]$ in combination with triphenylphosphine was employed by Kawatsura, Itoh and co-workers to catalyze the addition of different aromatic and aliphatic carboxylic acids to a series of 1-aryl3,3,3-trifluoropropynes (see Scheme 3). ${ }^{68}$ Remarkably, despite the unsymmetrical nature of these alkynes, the reactions proceeded in a complete regioselective manner, affording exclusively the enol esters 4 resulting from the addition of the carboxylate anion to the $\mathrm{Ar}-\mathrm{C}_{\mathrm{sp}}$ carbon in good yields. Concerning the stereochemistry, a complete $E$-selectivity (syn-addition) was observed. 


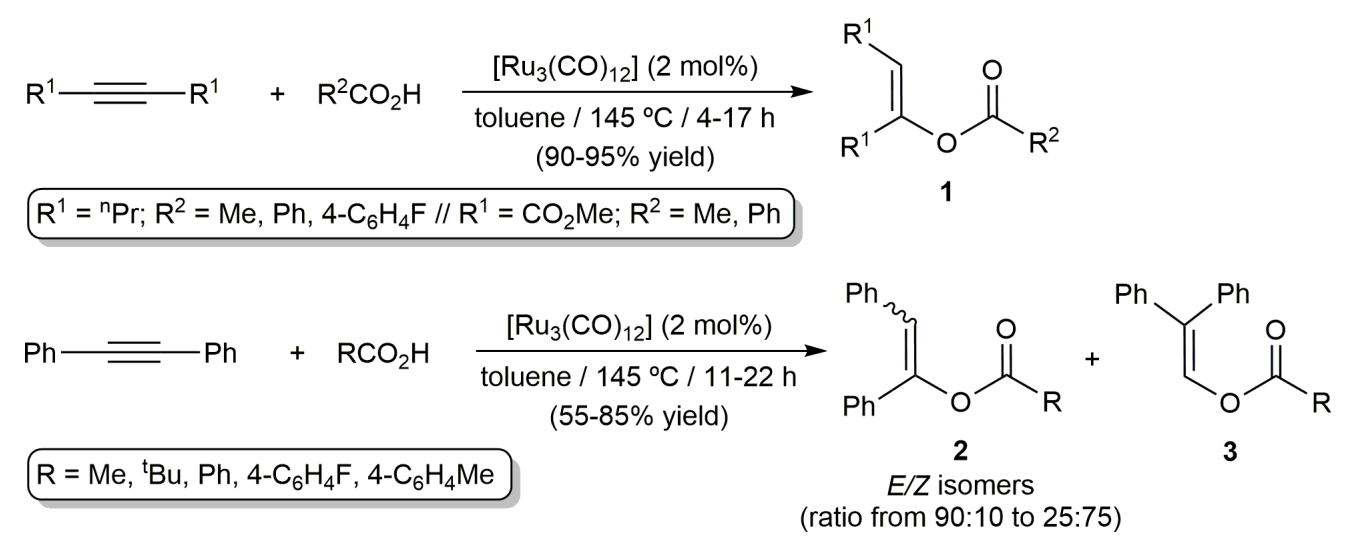

Scheme 2. $\left[\mathrm{Ru}_{3}(\mathrm{CO})_{12}\right]$-catalyzed hydro-oxycarbonylation of symmetrically substituted internal alkynes.

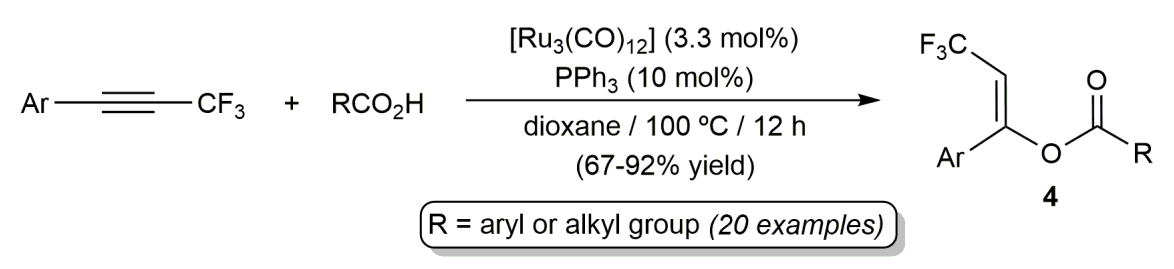

Scheme 3. Regio- and stereoselective access to trifluoromethyl-substituted enol esters.

From a mechanistic point of view, the reactions depicted in Schemes 2 and 3 seem to proceed through the initial formation of a carboxylate-ruthenium complex $\mathbf{I}$ to which the alkyne is subsequently coordinated (Scheme 4). Insertion of the alkyne into the Ru-O bond would then generate the intermediate II, which evolves into III by oxidative addition of a second molecule of the carboxylic acid. Final reductive elimination would liberate the enol ester product, regenerating the catalytically active species I. The studies by Rotem and Shvo strongly supported that all the intermediates involved in the catalytic cycle are of mononuclear nature, as a consequence of the fragmentation of the cluster precursor $\left[\mathrm{Ru}_{3}(\mathrm{CO})_{12}\right]$ upon reaction with the carboxylic acid and the alkyne. ${ }^{67}$ On the other hand, the rearranged products 3 commented above probably arise from intermediate II, via formation of the vinyl cation IV and subsequent 1,2-shift of one of the vinyl substituents (Scheme 4).

Although with limited examples, the group of Dixneuf also demonstrated the possibility of using the catalytic systems $\mathrm{RuCl}_{3} / 2 \mathrm{P}^{n} \mathrm{Bu}_{3}$ and $\left[\left\{\mathrm{Ru}\left(\mu-\mathrm{O}_{2} \mathrm{CH}\right)(\mathrm{CO})_{2}\left(\mathrm{PPh}_{3}\right)\right\}_{2}\right]$ to promote the hydro-oxycarbonylation of internal alkynes. In particular, the former was able to catalyze the addition of acetic acid to diphenylacetylene, in decalin at $160^{\circ} \mathrm{C}$, to afford the enol ester $\mathrm{PhCH}=\mathrm{CPh}(\mathrm{OCOMe}$ ) as a mixture of $Z / E$ stereoisomers in $c a .1 .5: 1$ ratio. ${ }^{69}$ For its side, $\left[\left\{\mathrm{Ru}\left(\mu-\mathrm{O}_{2} \mathrm{CH}\right)(\mathrm{CO})_{2}\left(\mathrm{PPh}_{3}\right)\right\}_{2}\right]$ was employed as catalyst for the addition of benzoic acid to the unsymmetrical alkynes 1-phenylpropyne and oct-2-yne in refluxing toluene, the reactions leading to mixtures of regioisomers (2:1 ratio) with complete stereoselectivity ( $Z$ isomers). ${ }^{70}$

On the other hand, employing the ruthenium-carbene complex $\left[\mathrm{Ru}\left(=\mathrm{CHPh} \mathrm{Cl}_{2}\left(\mathrm{PC}_{3}\right)(\mathrm{IPr})\right](\mathrm{IPr}=1,3-\right.$ bis(2,6-diisopropylphenyl)-1,3-dihydro-2H-imidazo-2-ylidene) as catalyst, Karabulut and co-workers examined the addition of trichloroacetic acid to 4-octyne, 3-hexyne and 2-hexyne under solvent-free conditions. Performing the reactions with $4 \mathrm{~mol} \%$ of Ru under remarkably mild conditions, i.e. $65{ }^{\circ} \mathrm{C}$, the desired enol esters were generated in good yields (73-75\% after $9 \mathrm{~h}$ ), albeit as mixtures of all the possible isomers in each case. ${ }^{71}$ In addition to its low selectivity, it is also of note that $\left[\mathrm{Ru}(=\mathrm{CHPh}) \mathrm{Cl}_{2}\left(\mathrm{PCy}_{3}\right)(\mathrm{IPr})\right]$ proved to be 
completely inactive when other carboxylic acids, such as acetic acid, trans-2-octenoic acid or 4-cyclooctenoic acid, were employed as substrates, pointing out its reduced scope.

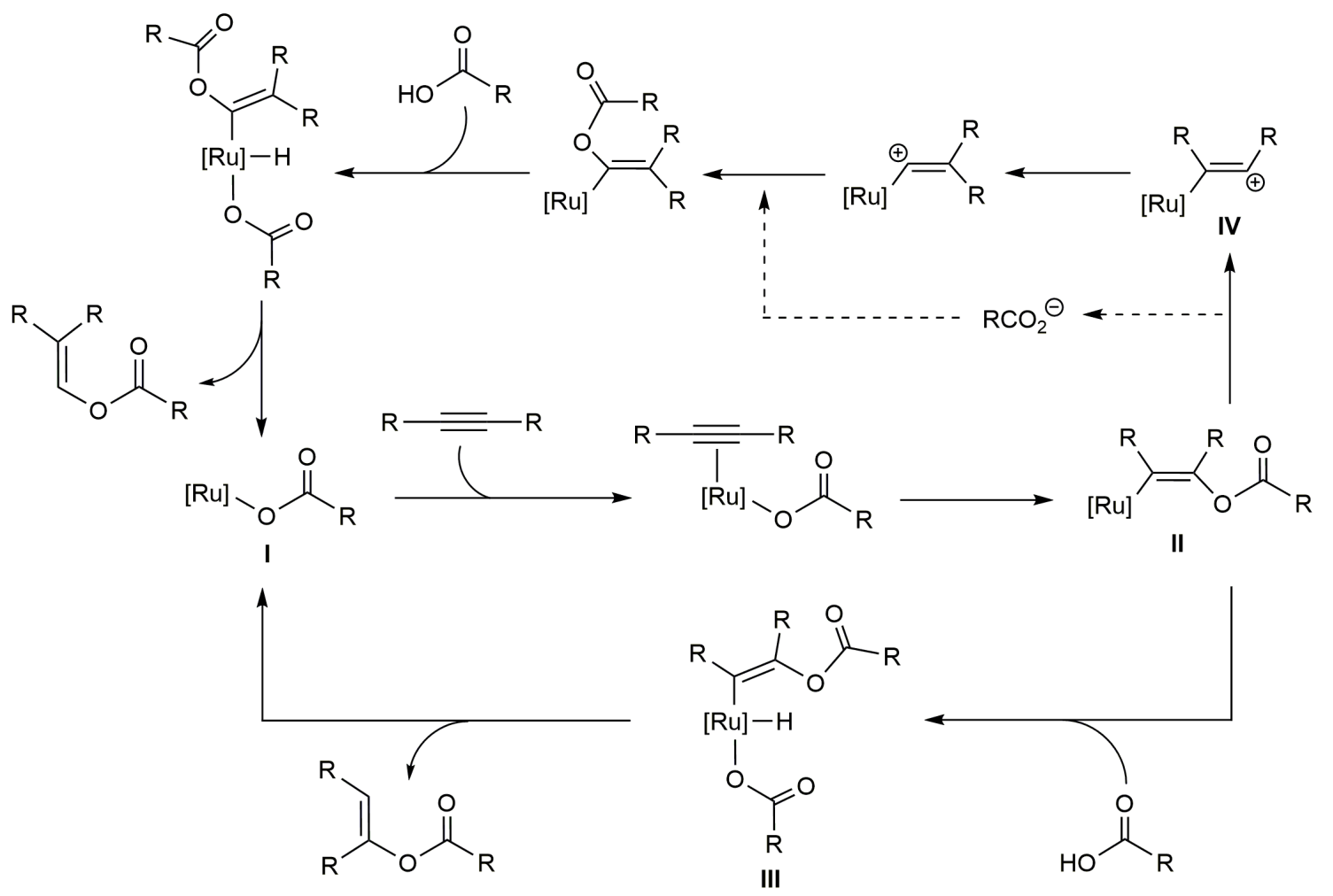

Scheme 4. Proposed mechanism for the formation of compounds 1-4.

Very recently, the mononuclear ruthenium(II) complex $\left[\mathrm{Ru}(\mathrm{CO})_{2}\left\{\mathrm{P}\left(4-\mathrm{C}_{6} \mathrm{H}_{4} \mathrm{CF}_{3}\right)_{3}\right\}_{2}\left(\mathrm{O}_{2} \mathrm{CPh}\right)_{2}\right](\mathbf{5})$, developed by Lang's group, has emerged as one of the most powerful catalysts for the hydro-oxycarbonylation of acetylenic systems. ${ }^{72,73}$ In this regard, in combination with the Lewis acid $\mathrm{B}\left(\mathrm{C}_{6} \mathrm{~F}_{5}\right)_{3}$, complex 5 was able to catalyze the addition of different carboxylic acids to both activated and unactivated internal alkynes with complete syn-selectivity, affording a broad range of trisubstituted $(E)$-enol esters in high yields (Scheme 5). ${ }^{73}$ Unfortunately, in the case of unsymmetrically substituted substrates, the regioselectivity of the process could not be controlled, and mixtures of the two regioisomeric syn-addition products $\mathbf{6}$ and $\mathbf{7}$ were in all the cases obtained. However, we must note that some influence of the $\mathrm{C} \equiv \mathrm{C}$ bond substituents on the regioselectivity of the process was observed, increasing as the substituents become more electronically or sterically dissimilar. Concerning the mechanism, a reaction pathway similar to that depicted in Scheme 4 was proposed, with the Lewis acid $\mathrm{B}\left(\mathrm{C}_{6} \mathrm{~F}_{5}\right)_{3}$ facilitating the reaction by enhancing the acidity of the carboxylic acid via carbonyl oxygen coordination, or by further activating the Ru-coordinated alkyne substrate through a secondary $\pi$-interaction of the $C \equiv C$ bond with the boron atom. Regardless of its way of acting, the experimental fact is that, in the absence of $\mathrm{B}\left(\mathrm{C}_{6} \mathrm{~F}_{5}\right)_{3}$, the catalytic activity of $\left[\mathrm{Ru}(\mathrm{CO})_{2}\left\{\mathrm{P}\left(4-\mathrm{C}_{6} \mathrm{H}_{4} \mathrm{CF}_{3}\right)_{3}\right\}_{2}\left(\mathrm{O}_{2} \mathrm{CPh}\right)_{2}\right](5)$ is significantly reduced. 

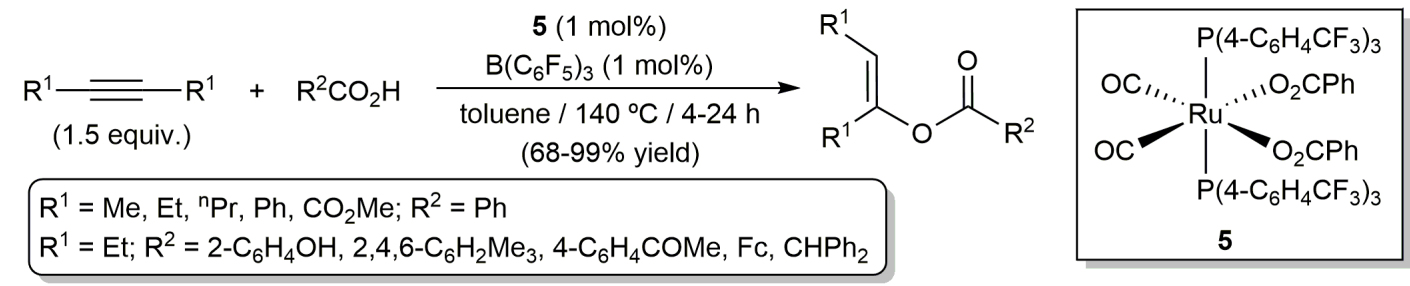

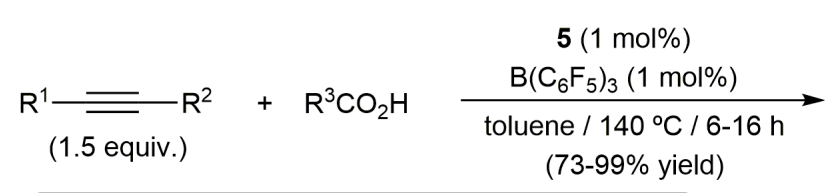

$\mathrm{R}^{1}={ }^{\mathrm{n}} \mathrm{Pr} ; \mathrm{R}^{2}=\mathrm{Me} ; \mathrm{R}^{3}=\mathrm{Ph}, 4-\mathrm{C}_{6} \mathrm{H}_{4} \mathrm{OMe}, 4-\mathrm{C}_{6} \mathrm{H}_{4} \mathrm{CF}_{3}$

$R^{1}={ }^{n} B u ; R^{2}=E t, P h ; R^{3}=P h$

$R^{1}=P h ; R^{2}=M e ; R^{3}=P h$

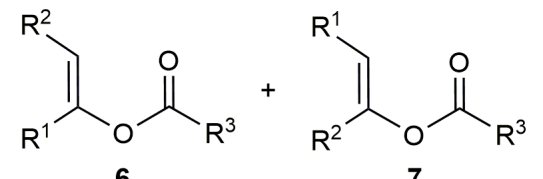

$6 / 7$ ratios from $56: 44$ to $72: 28$

Scheme 5. Addition of carboxylic acids to internal alkynes employing the Ru(II) complex $\mathbf{5}$ as catalyst.

\subsection{Palladium-based catalysts}

The first use of a palladium catalyst for the reaction under study was described by Lu and co-workers in 1992 with the regio- and stereoselective hydroacetoxylation of the 2-alkynoate esters 8 (Scheme 6). ${ }^{74}$ Thus, by reacting $\mathbf{8}$ with a stoichiometric amount of lithium or sodium acetate in acetic acid at r.t., in the presence of 5 mol\% of $\mathrm{Pd}(\mathrm{OAc})_{2}$, a series of (Z)-enol acetates 9 could be selectively synthesized in moderate to high yields. The authors proposed the initial formation of an alkenyl-palladium intermediate by trans attack of the acetate anion at the C-3 carbon of the coordinated substrate, and subsequent protodemetalation with complete retention of the configuration of the double bond formed in the first step. The whole process entails the anti addition of acetic acid to the 2-alkynoate esters $\mathbf{8}$.

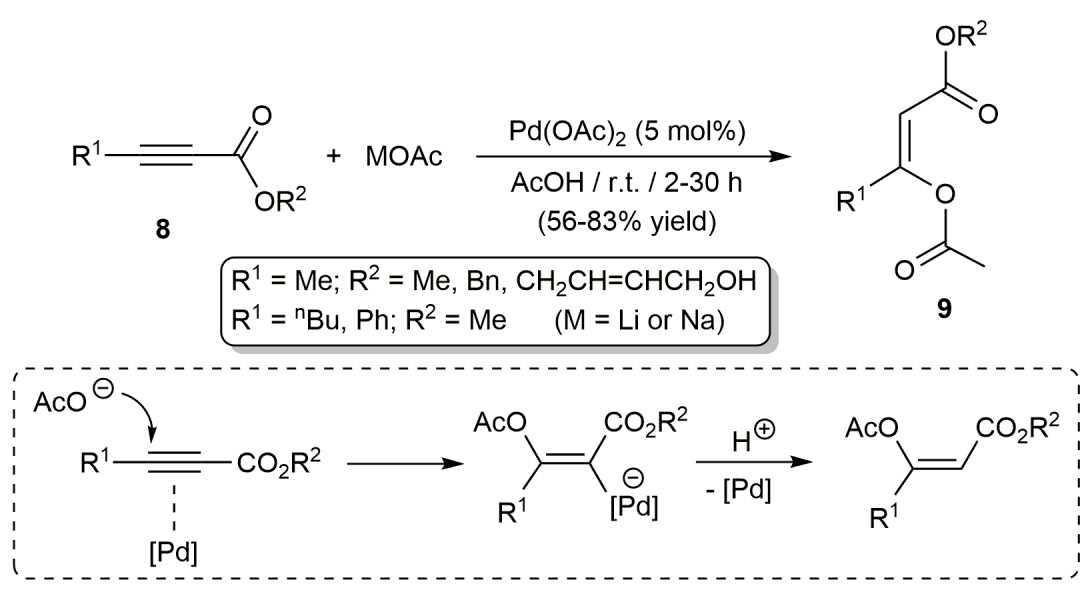

Scheme 6. Pd-catalyzed selective hydroacetoxylation of 2-alkynoate esters 8.

Three years later, the group of Hidai reported the mixed-metal cubane-type cluster complex $\left[\mathrm{PdMo}_{3} \mathrm{~S}_{4}(\operatorname{tacn})_{3} \mathrm{Cl}\right]\left[\mathrm{PF}_{6}\right]_{3}$ (tacn = 1,4,7-triazacyclononane; see Figure 1 ) as a highly efficient and selective catalyst for the addition of carboxylic acids to acetylenic derivatives activated with electron-withdrawing substituents. ${ }^{75}$ Although his work focused mainly on terminal alkynes, the addition of acetic acid to the internal substrates $\mathrm{RC} \equiv \mathrm{CCO}_{2} \mathrm{Me}\left(\mathrm{R}=\mathrm{Me}, \mathrm{CO}_{2} \mathrm{Me}\right)$ was also considered. In this regard, performing the reactions with only 0.06 mol\% of complex 10 , in acetonitrile at $40{ }^{\circ} \mathrm{C}$ and in the presence of triethylamine, the 
trisubstituted enol esters $(Z)-\mathrm{RC}(\mathrm{OAC})=\mathrm{CHCO}_{2} \mathrm{Me}$ were regio- and stereoselectively generated in $65-81 \%$ yield after 10-48 h. A mechanism analogous to that depicted in Scheme 6, involving again a key alkenyl-palladium intermediate, was suggested (anti addition).

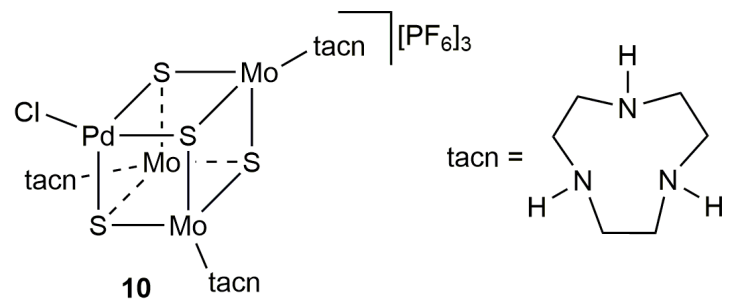

Figure 1. Structure of the cluster complex 10.

More recently, the $\mathrm{Pd}(\mathrm{OAc})_{2}$-catalyzed hydro-oxycarbonylation of ynamides $\mathbf{1 1}$ was described by Lam and co-workers. ${ }^{76}$ As shown in Scheme 7, the addition of the carboxylic acid to the $\mathrm{C} \equiv \mathrm{C}$ of the substrates proceeded in a completely regio- and stereoselective manner, providing the $\alpha$-acyloxyenamides 12 in moderate to high yields. It is worth noting that, while the regioselectivity observed in these reactions is not surprising since the addition of heteroatom nucleophiles to the triple bond of ynamides usually occurs $\alpha$ to the nitrogen atom, ${ }^{77-79}$ the stereochemical outcome (syn addition) is opposite to the examples just discussed above (anti addition). Although the authors did not dare to propose a conclusive mechanism, they briefly commented two different possibilities, involving: (i) the initial generation of a palladium-hydride intermediate by oxidative addition of the carboxylic acid to in situ formed $\mathrm{Pd}(0)$ species, followed by hydropalladation of the ynamide and final $\mathrm{C}-\mathrm{O}$ reductive elimination, or (ii) the addition of the carboxylate anion to in situ generated $N$-acylketeniminium intermediates.

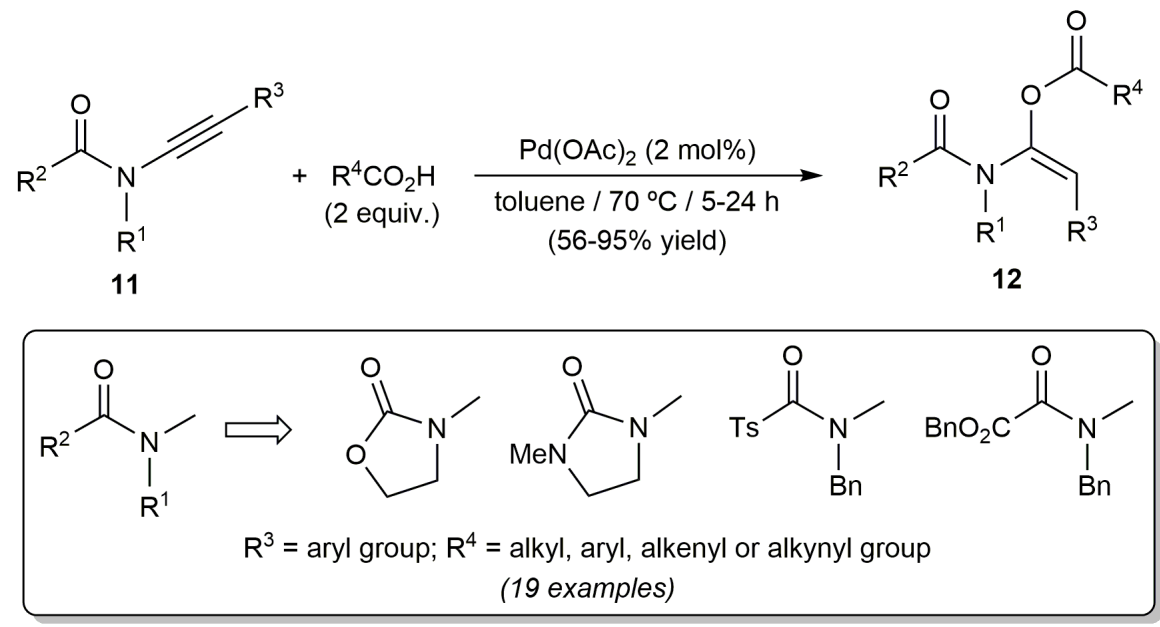

Scheme 7. Pd-catalyzed hydro-oxycarbonylation of ynamides.

Albeit in only one article, the palladium-catalyzed intermolecular addition of carboxylic acids to unactivated internal alkynes can also be found in the literature. In particular, Tsukada and co-workers found that, in combination with $\mathrm{B}^{\mathrm{n} B u_{3}}$, the dinuclear species $\mathbf{1 3}$ is able to promote such reactions leading to the corresponding anti-addition products (Scheme 8). ${ }^{80}$ However, it should be noted that yields were generally low and that, in the case of unsymmetrically substituted alkynes, mixtures of regioisomers were obtained (compounds 14 and 15 ). A reaction mechanism with participation of both $\mathrm{Pd}$ atoms of the catalyst, one 
activating the alkyne by $\pi$-coordination and the other one the carboxylic acid by generation of a carboxylate complex, was proposed.
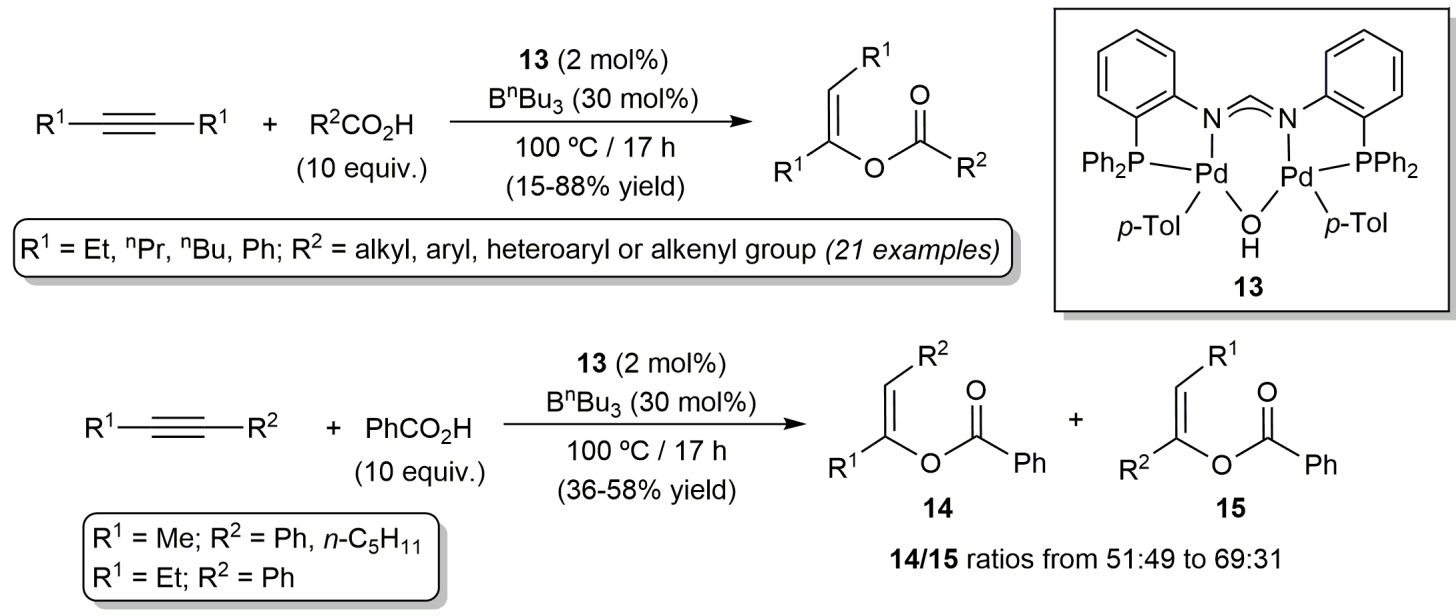

Scheme 8. Pd-catalyzed hydro-oxycarbonylation of unactivated internal alkynes.

Finally, a recent and very interesting result in the field was described by Hirao, Yoshikai and co-workers while studying the palladium-catalyzed addition of carboxylic acids to the alkynylbenziodoxoles 16 (Scheme 9). ${ }^{81}$ The reactions, which were promoted by the $\left[\mathrm{Pd}(\mathrm{OAc})(2 \text {-methylallyl) }]_{2} / 1,5\right.$-cyclooctadiene system under very mild conditions (r.t.), led to the selective formation of the alkenylbenziodoxoles 17 . Density functional theory (DFT) calculations indicated that this unprecedented rearrangement/addition process involves the formation of a Pd-vinylidene intermediate VI, via 1,2-shift of the iodine(III) fragment on the initially formed $\pi$ alkyne species V. Then, a formal 1,1-hydroxycarboxylation takes place by nucleophilic addition of the carboxylate anion on the $\alpha$-carbon of the vinylidene intermediate $\mathbf{V I}$, and subsequent protodemetalation of the resulting alkenyl-palladate VII. Remarkably, the scope of the reaction and its functional group tolerance were very high, and the synthetic utility of the alkenylbenziodoxole products $\mathbf{1 7}$ could be demonstrated by their participation in different C-C coupling processes (Stille, Sonogashira and Kumada reactions), giving access to different sterochemically well-defined trisubstituted enol esters.

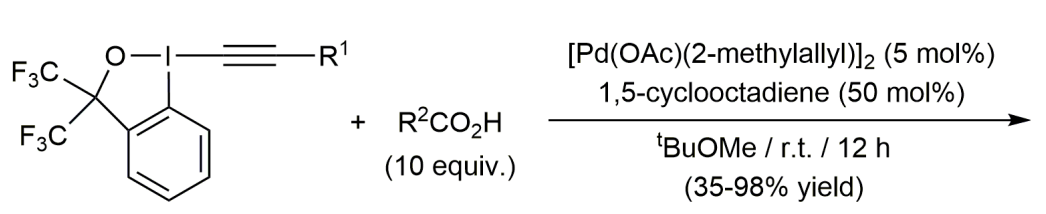

16

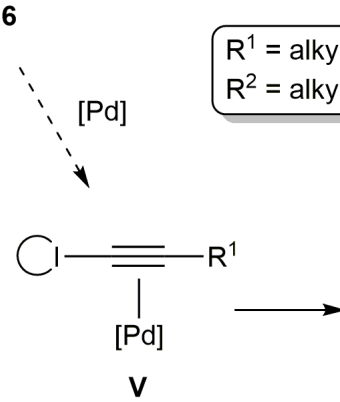

$\mathrm{R}^{1}=$ alkyl, aryl, heteroaryl, alkenyl or alkynyl group $\mathrm{R}^{2}=$ alkyl, aryl or heteroaryl group (22 examples)
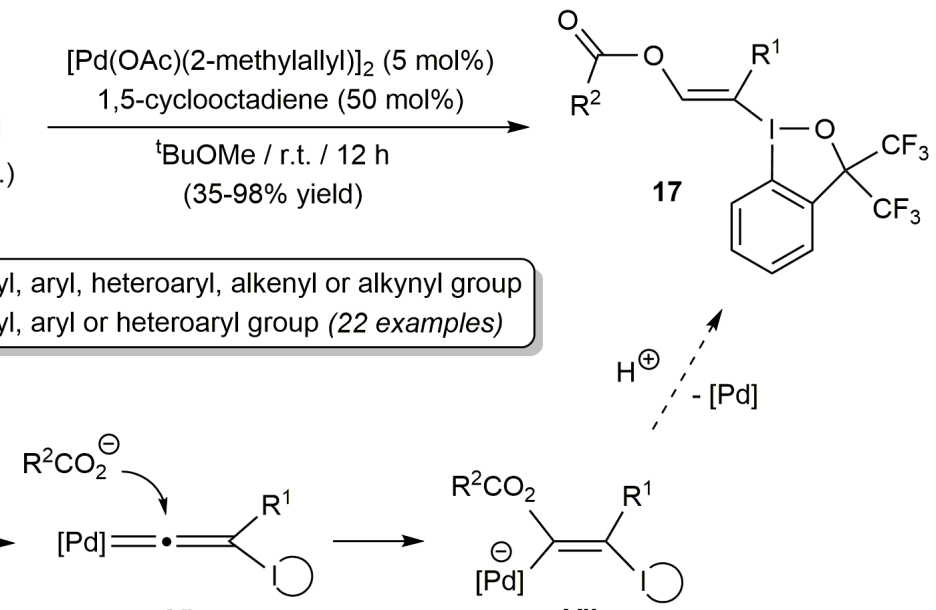

VI

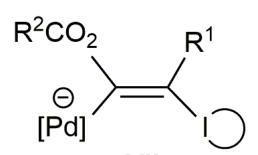

VII

Scheme 9. Pd-catalyzed addition of carboxylic acids to alkynylbenziodoxoles 16. 


\subsection{Silver-based catalysts}

Although silver salts represent ideal and cheap catalysts for alkyne-based organic reactions, their involvement in hydro-oxycarbonylations has been scarcely documented and mainly restricted to intramolecular processes, i.e. the cycloisomerization of alkynoic acids. ${ }^{82}$ However, in 1981 Ishino and co-workers reported a solvent-free silver-catalyzed intermolecular addition of carboxylic acids to alkynes able to operate with activated symmetrically substituted internal substrates (Scheme 10). ${ }^{83}$ Among the different $\mathrm{Ag}(\mathrm{I})$ sources employed, $\mathrm{Ag}_{2} \mathrm{CO}_{3}$ exhibited the best reactivity, affording the enol ester products as mixtures of $E / Z$ stereoisomers (major stereoisomer not indicated). A classical mechanism involving the initial $\pi$-coordination of the alkyne to the silver cation, followed by nucleophilic attack of the carboxylate anion and final protonolysis was suggested to account for the formation of the products. Anti-addition products are initially formed, isomerizing to the syn ones with time under the thermal conditions employed.

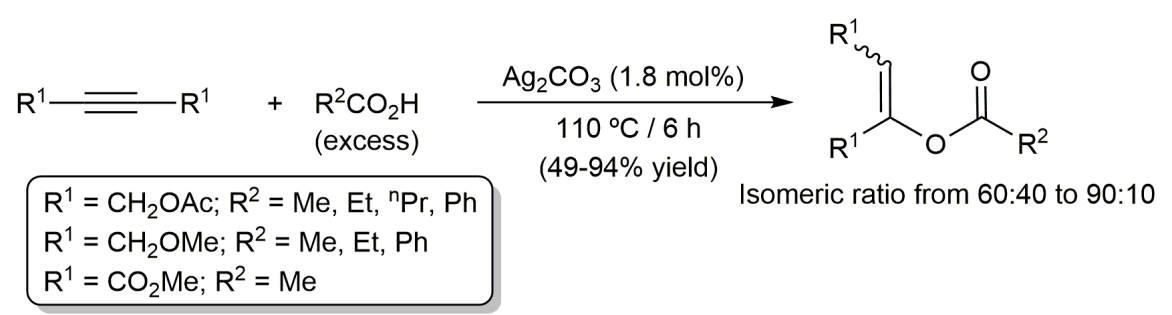

Scheme 10. Silver-catalyzed addition of carboxylic acids to activated internal alkynes.

More recently, Zhu and coworkers described a wide scope procedure for the regio- and stereoselective addition of carboxylic acids to ynol ethers 18 employing $\mathrm{Ag}_{2} \mathrm{O}(5 \mathrm{~mol} \%)$ as catalyst. ${ }^{84}$ The reactions, which were performed in dioxane at $100{ }^{\circ} \mathrm{C}$, afforded the (Z)- $\alpha$-alkoxy-enol esters 19 in 40-95\% yields (Scheme 11). Interestingly, the use of other $\mathrm{Ag}(\mathrm{I})$ sources or different metals (Ru(O), $\mathrm{Cu}(\mathrm{I}), \mathrm{Cu}(\mathrm{II}), \mathrm{Zn}(\mathrm{II})$ and $\mathrm{Au}(\mathrm{I})$ species) resulted in much lower yields in comparison to $\mathrm{Ag}_{2} \mathrm{O}$. On the other hand, the subsequent Ni-catalyzed SuzukiMiyaura coupling of compounds 19 allowed the preparation of different trisubstituted enol ethers 20, the overall process representing a convenient method for the trans-hydroarylation of ynol ethers. A reaction pathway analogous to that comented in the previous example was proposed for the addition process (Scheme 11).
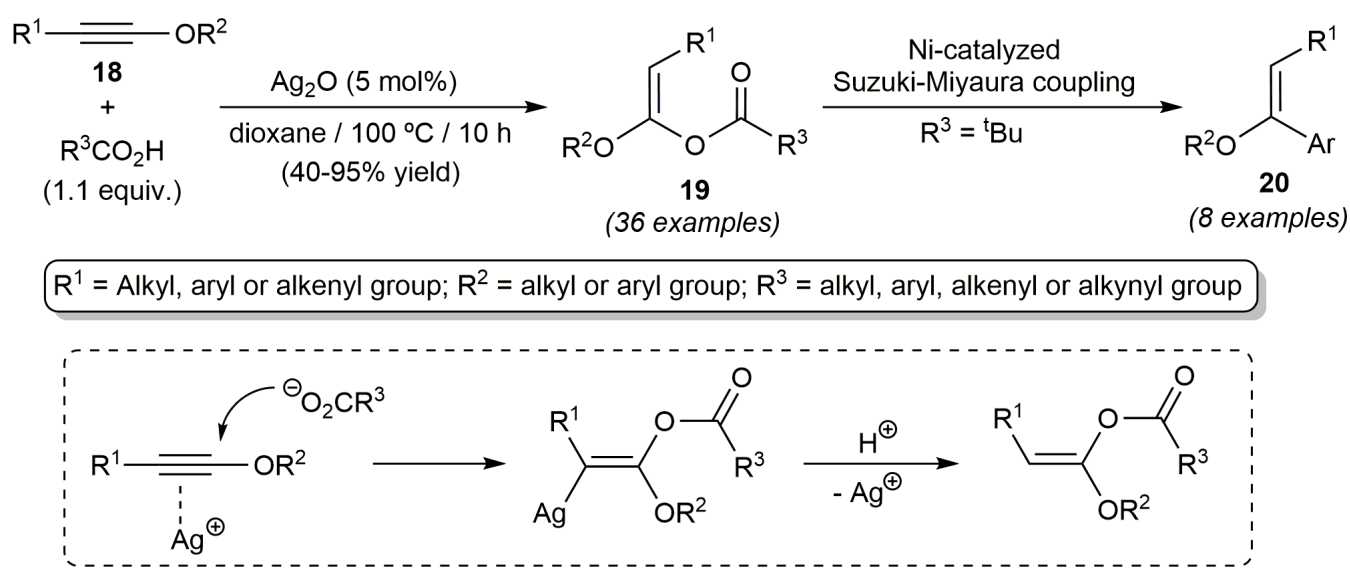

Scheme 11. Silver-catalyzed hydro-oxycarbonylation of ynol ethers 18. 


\subsection{Gold-based catalysts}

Gold derivatives have emerged in recent years as the most effective systems for the electrophilic $\pi$-activation of unsaturated carbon-carbon bonds, ${ }^{85,86}$ so it is not surprising that they have also been employed as catalysts for the hydro-oxycarbonylation of alkynes. In this regard, the first example, reported by Schmidbaur and coworkers in 2004, ${ }^{87}$ involved the anti-addition of acetic acid to EtC $\equiv C E t$ promoted by the carboxylate-phosphine $\mathrm{Au}(\mathrm{I})$ complex $\left[\mathrm{Au}\left(\mathrm{O}_{2} \mathrm{CC}_{2} \mathrm{~F}_{5}\right)\left(\mathrm{PPh}_{3}\right)\right](0.134 \mathrm{~mol} \%)$ and $\mathrm{BF}_{3} \cdot \mathrm{Et}_{2} \mathrm{O}(5.25 \mathrm{~mol} \%)$. However, we must note that the reaction, which was performed in tetrahydrofuran at $60^{\circ} \mathrm{C}$ for $1 \mathrm{~h}$, afforded (Z)-EtCH=CEt(OAC) in a very low yield, i.e. only $6 \%$ ( $12 \%$ of 3 -hexanone resulting from the hydration of EtC $\equiv C E t$ was also formed). A more general study was published by Chary and Kim in 2010 employing the catalytic system $\left[\mathrm{AuCl}\left(\mathrm{PPh}_{3}\right)\right] / \mathrm{AgPF}_{6}(5$ mol\%). ${ }^{88}$ Thus, they found that, in toluene at $60-110{ }^{\circ} \mathrm{C}$, the in situ formed $\left[\mathrm{Au}\left(\mathrm{PPh}_{3}\right)\right]^{+}$cation cleanly and efficiently catalyzes the anti-addition of different carboxylic acids to both terminal and internal alkynes. With regard to the latter, the results obtained in the four reactions covered by Chary and Kim are shown in Scheme 12. Remarkably, starting from the unsymmetrically substituted alkynes $P h C \equiv C R\left(R=C_{2} E t, M e\right)$ a complete regioselectivity was observed, with the carboxylate adding to the $\mathrm{Ar}-\mathrm{C}_{\mathrm{sp}}$ carbon exclusively.

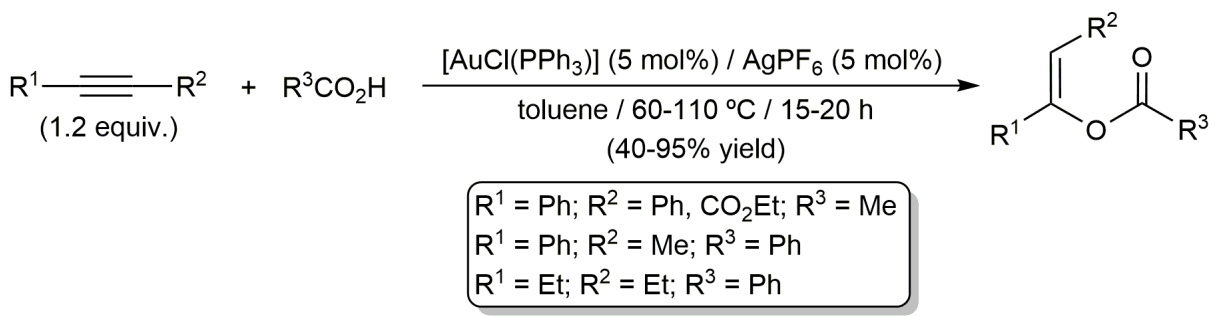

Scheme 12. [AuCl(PPh 3$)] / \mathrm{AgPF}_{6}$-catalyzed addition of carboxylic acids to internal alkynes.

Employing the same catalytic system, a large variety of (Z)- $\beta$-iodoenol esters $\mathbf{2 2}$ could also be obtained under mild conditions (r.t.) by Cadierno and co-workers employing the 1-iodoalkynes $\mathbf{2 1}$ as starting materials (Scheme 13). ${ }^{89,90} \mathrm{~A}$ classical reaction pathway involving the nucleophilic attack of the carboxylate anion to the more electrophilic C-2 carbon of the $\pi$-activated iodoalkyne (nucleophilic attacks to haloalkynes commonly takes place on the C-2 carbon), ${ }^{91}$ followed by protodematalation was proposed. As usual in the chemistry of $\pi$ alkyne-gold complexes, and in a similar way to the previously mentioned examples, the addition of the carboxylic acids proceeds in an anti-fashion. On the other hand, it is also worth mentioning that compounds 22 were successfully employed as precursors for the preparation of other stereochemically defined trisubstituted enol esters $\mathbf{2 3}$ and $\mathbf{2 4}$ through Pd-catalyzed Suzuki-Miyaura and Sonogashira cross-coupling processes. ${ }^{89,90,92}$

Interestingly, the same group also demonstrated that $\left[\mathrm{AuCl}\left(\mathrm{PPh}_{3}\right)\right]$, now in combination with $\mathrm{AgOAc}$, can be employed to promote the intermolecular addition of carboxylic acids to internal alkynes in environmentally friendly aqueous medium, ${ }^{93}$ representing a rare example of this type of reactions in water (Scheme 14). ${ }^{94}$ Enols esters resulting from the expected anti-addition of the acid to the $\mathrm{C} \equiv \mathrm{C}$ bond were exclusively formed at $60{ }^{\circ} \mathrm{C}$, not observing in any case the formation of carbonylic products derived from the hydration of the alkynes. Both activated and unactivated alkynes were successfully employed and, in the case of unsymmetrically substituted substrates, a complete regioselectivity was achieved when one electronwithdrawing group $\left(\mathrm{CO}_{2} \mathrm{Me}, \mathrm{CO}_{2} \mathrm{Et}\right.$ or $\left.\mathrm{CN}\right)$ was present. 


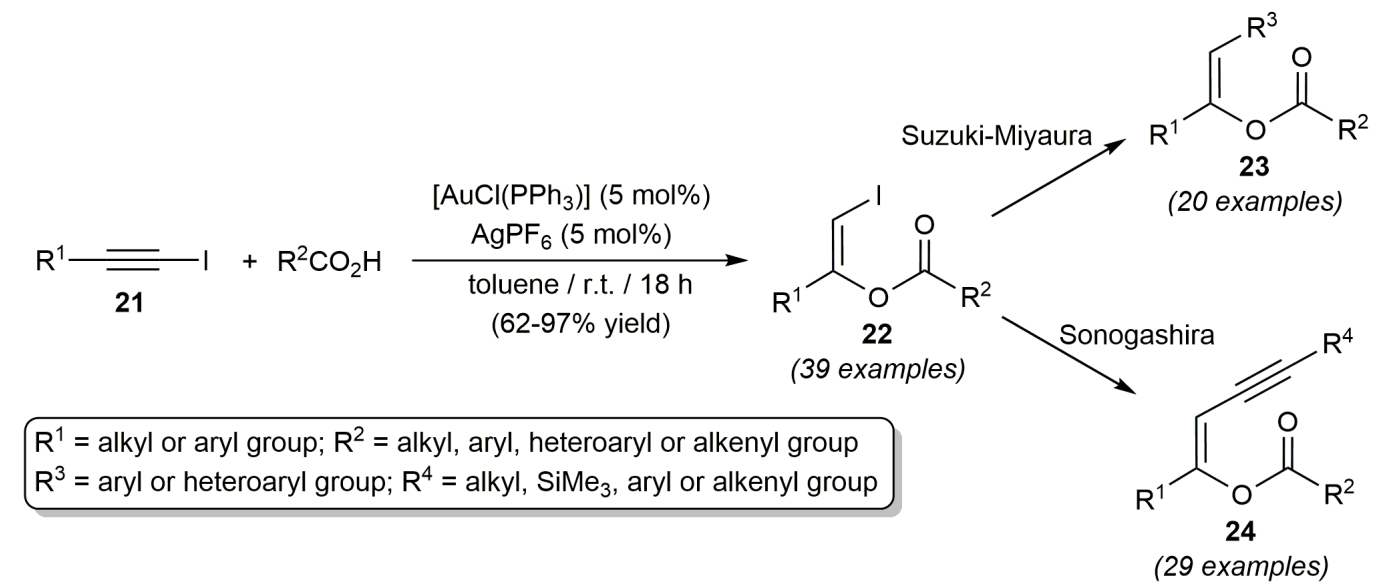

Scheme 13. Synthesis and C-C coupling reactions of (Z)- $\beta$-iodoenol esters 22.

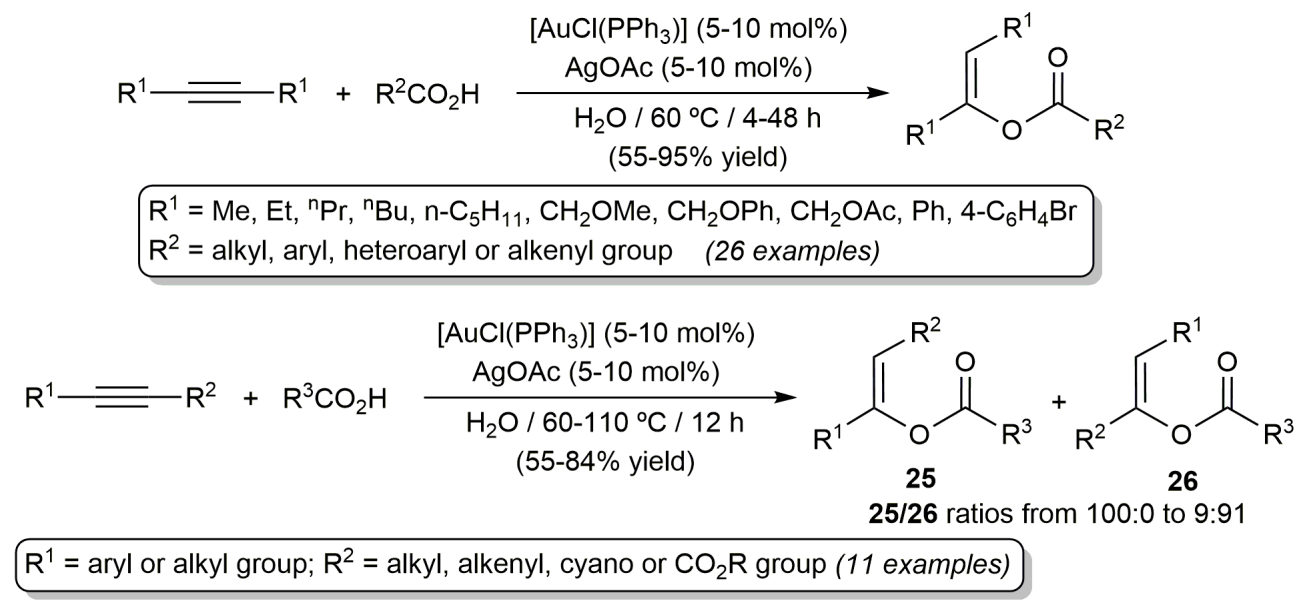

Scheme 14. Gold-catalyzed hydro-oxycarbonylation of internal alkynes in water.

In addition to $\left[\mathrm{AuCl}\left(\mathrm{PPh}_{3}\right)\right]$, the use of other two gold(I) catalysts, i.e. $\mathbf{2 7}$ and $\mathbf{2 8}$ in Figure 2, for the hydrocarboxylation of alkynes has been described. ${ }^{95,96}$ The former, developed by Zhang and co-workers, ${ }^{95}$ was able, in combination with $\mathrm{NaBArF}$, to promote the addition of benzoic acid to the internal alkynes nPentC $\equiv C^{n}$ Pent, $\mathrm{PhC} \equiv \mathrm{CCO}_{2} \mathrm{Et}$ and $\mathrm{MeC} \equiv \mathrm{CCH}_{2} \mathrm{CH}_{2} \mathrm{OBn}$ in fluorobenzene at $80^{\circ} \mathrm{C}$. The reactions, performed with very low metal loadings (0.015-0.15 mol\%), led to the expected anti-addition products in very high yields (85\%-99\%) after 15-20 h. Concerning the regioselectivity of the process, starting from $\mathrm{PhC} \equiv \mathrm{CCO}_{2} \mathrm{Et}$ the addition of the benzoate group took place exclusively on the $\mathrm{Ph}-\mathrm{C}_{\mathrm{sp}}$ carbon, while in the case of $\mathrm{MeC} \equiv \mathrm{CCH}_{2} \mathrm{CH}_{2} \mathrm{OBn}$ a mixture of regioisomers was obtained. Remarkably, DFT calculations supported the role of the amide group of the biaryl-phosphine ligand in directing the attack of the carboxylic acid to the $\pi$ coordinated $\mathrm{C} \equiv \mathrm{C}$ bond via hydrogen bonding. 


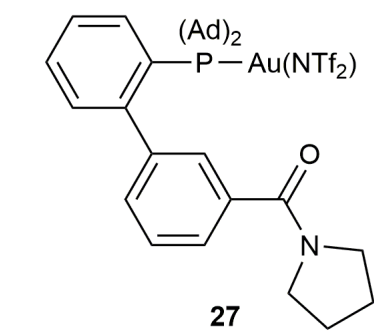

$\mathrm{Ad}=1$-adamantanyl

$\mathrm{NTf}_{2}=$ bis(trifluoromethylsulfonyl)amide

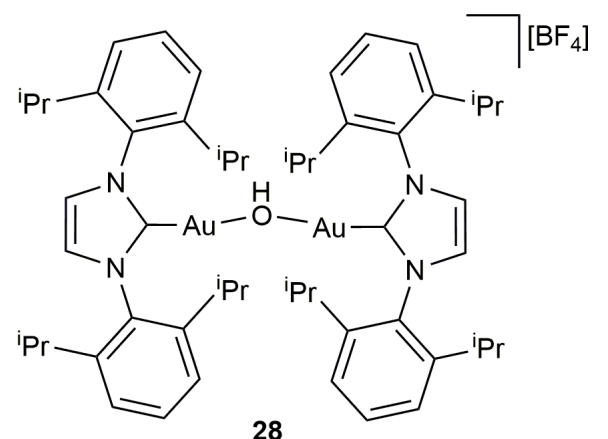

28

Figure 2. Structure of the gold(I) catalysts $\mathbf{2 7}$ and 28.

For its side, the digold hydroxide complex 28, developed by Nolan and co-workers, ${ }^{96}$ showed a very high activity and wide scope under solvent- and silver-free conditions. Both activated and unactivated internal alkynes could be hydro-oxycarbonylated with a large variety of carboxylic acids (aromatic, heteroaromatic, aliphatic, $\alpha, 6$-unsaturated and even with formic acid) using $0.5 \mathrm{~mol} \%$ of this complex at $80{ }^{\circ} \mathrm{C}$, leading to the corresponding ( $Z$ )-enol esters in high yields (anti addition). Moreover, a complete or very high regioselectivity was achieved with $\mathbf{2 8}$ in the reactions of unsymmetrically substituted alkynes (representative examples are shown in Figure 3). Participation of the two gold centres, after splitting of the initial dinuclear structure, in the catalytic reaction (one activating the alkyne and the other one the carboxylic acid) was proposed by the authors.
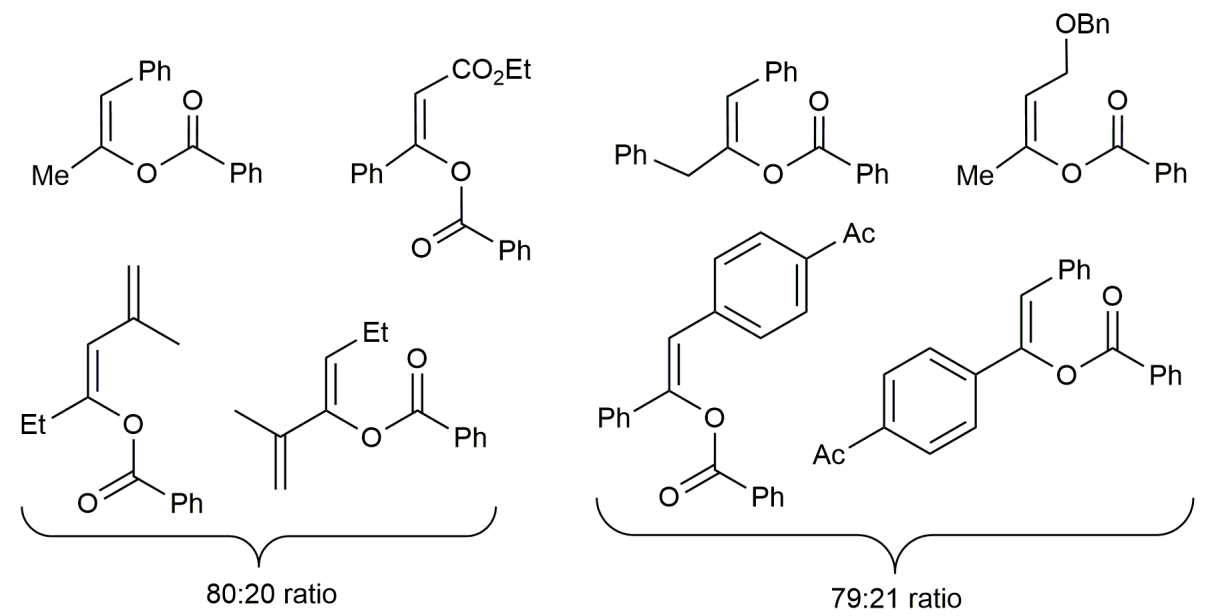

Figure 3. Some representative enol esters synthesized using complex 28.

\section{Metal-Free Reactions}

Although rare, some metal-free protocols for the hydro-oxycarbonylation of alkynes are known. However, most of them have a limited scope, being restricted to substrates containing highly activated $\mathrm{C} \equiv \mathrm{C}$ bonds. This is the case of ynamides 11, in which the presence of a nitrogen atom adjacent to the alkyne function renders the $\mathrm{C} \equiv \mathrm{C}$ bond much more reactive compared to that of standard alkynes. ${ }^{77-79}$ In this context, $\mathrm{Hu}, \mathrm{Bi}$ and coworkers demonstrated that no metals are needed to promote the addition of carboxylic acids to ynamides $\mathbf{1 1}$, 
the formation of compounds 12 (see Scheme 7) taking place just by heating 11 in the presence of the corresponding acid ( 1.5 equiv.) in toluene at $100{ }^{\circ} \mathrm{C}(52-99 \%$ isolated yields after $1 \mathrm{~h}) .{ }^{97}$ Further studies carried out by other research groups revealed the possibility of carrying out these addition processes under milder conditions, i.e. in $\mathrm{CH}_{2} \mathrm{Cl}_{2}$ at r.t., although the reaction times required in these cases were much longer (12-65 h). 98,99

N-Alkynylated sulfoximines $\mathbf{2 9}$ are structurally related to ynamides and recent studies by Bolm and coworkers have shown their greater reactivity in various transformations. ${ }^{100-103}$ In particular, in what concerns the chemistry covered here, these highly activated alkynes are prone to undergo the regioselective catalystfree addition of carboxylic acids under remarkably mild reaction conditions (even at $-20{ }^{\circ} \mathrm{C}$ ). As shown in Scheme 15, performing the reactions in THF at r.t., different enol esters $\mathbf{3 0}$ could be synthesized in moderate to gold yields, in only $1 \mathrm{~h}$, and with excellent stereoselectivities. ${ }^{103}$
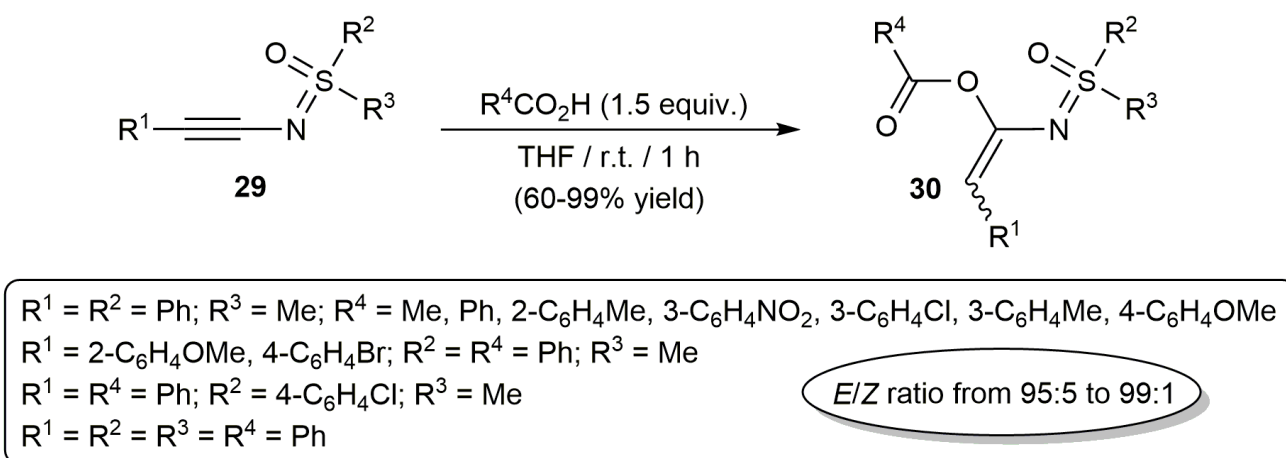

Scheme 15. The addition carboxylic acids to $N$-alkynylated sulfoximines.

The group of Severin demonstrated with a couple of examples that, similarly to ynamides and $N$ alkynylated sulfoximines, 1-alkynyltriazenes can also undergo hydro-oxycarbonylation reactions in the absence of any catalyst. Thus, as shown in Scheme 16, the treatment of 3,3-diisopropyl-1-(phenylethynyl)triazene 31 with acetic or benzoic acid, in toluene at $100{ }^{\circ} \mathrm{C}$ for $24 \mathrm{~h}$, results in the high yield and regioselective formation of the olefinic triazenes $\mathbf{3 2}$, with a marked preference for the corresponding $E$ isomers. ${ }^{104}$

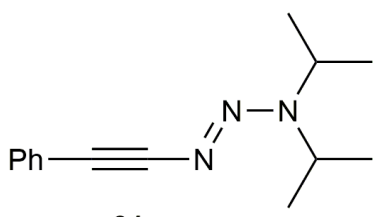

31

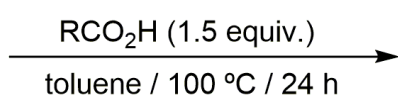

$(91-94 \%$ yield $)$

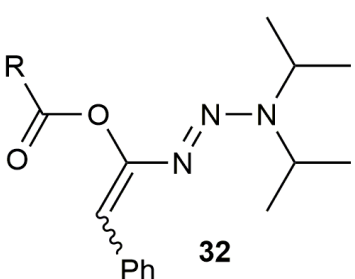

$\mathrm{R}=\mathrm{Me}(E / Z=88: 12), \mathrm{Ph}(E / Z=95: 5)$

Scheme 16. Hydro-oxycarbonylation reactions of 3,3-diisopropyl-1-(phenylethynyl)triazene 31.

On the other hand, Liang and co-workers described the stereoselective addition of various carboxylic acids to dimethyl acetylenedicarboxylate (DMAD) under mild conditions catalyzed by the organic base 1,4diazabicyclo[2.2.2] octane (DABCO) (Scheme 17). ${ }^{105} \mathrm{~A}$ reaction mechanism involving the initial formation of the zwitterionic intermediate VIII from DABCO and DMAD was proposed. Subsequent protonation of VIII by the 
carboxylic acid generates the cationic olefin IX, which then undergoes Michael addition of the carboxylate anion to give the intermediate species $\mathbf{X}$. Final elimination of DABCO from $\mathbf{X}$ affords the enol ester product.

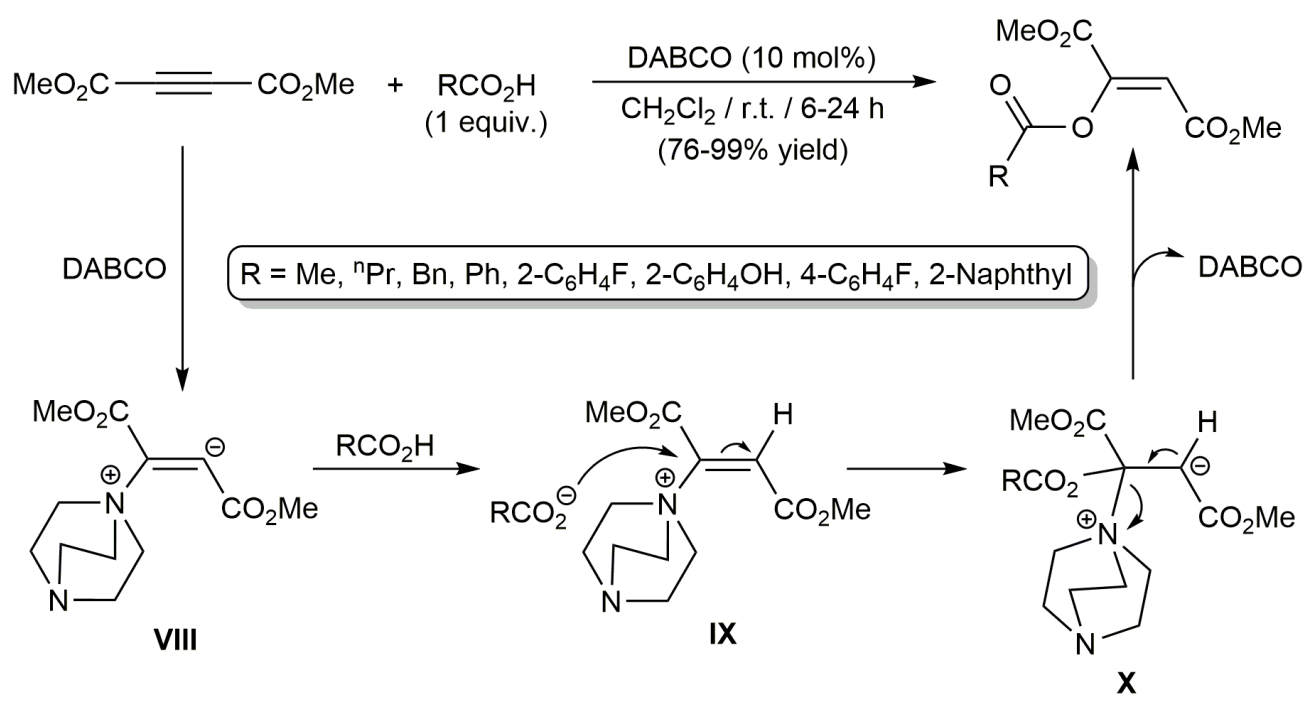

Scheme 17. DABCO-catalyzed addition of carboxylic acids to DMAD.

Of particular interest in the field are the works carried out by Trofimov and co-workers with the cyanopropargylic alcohols 33. Thus, as shown in Scheme 18, in the presence of triethylamine, they react with an stoichiometric amount of different benzoic acids to afford the 4-cyano-3(2H)-furanones $34 .{ }^{106,107}$ The process, which proceeds under very mild conditions, involves the initial amine-mediated addition of the carboxylic acid to the $\mathrm{C} \equiv \mathrm{C}$ bond of 33 , followed by a domino reaction sequence (intramolecular transesterification, keto-enol tautomerization and final Knoevenagel-Claisen-type condensation).
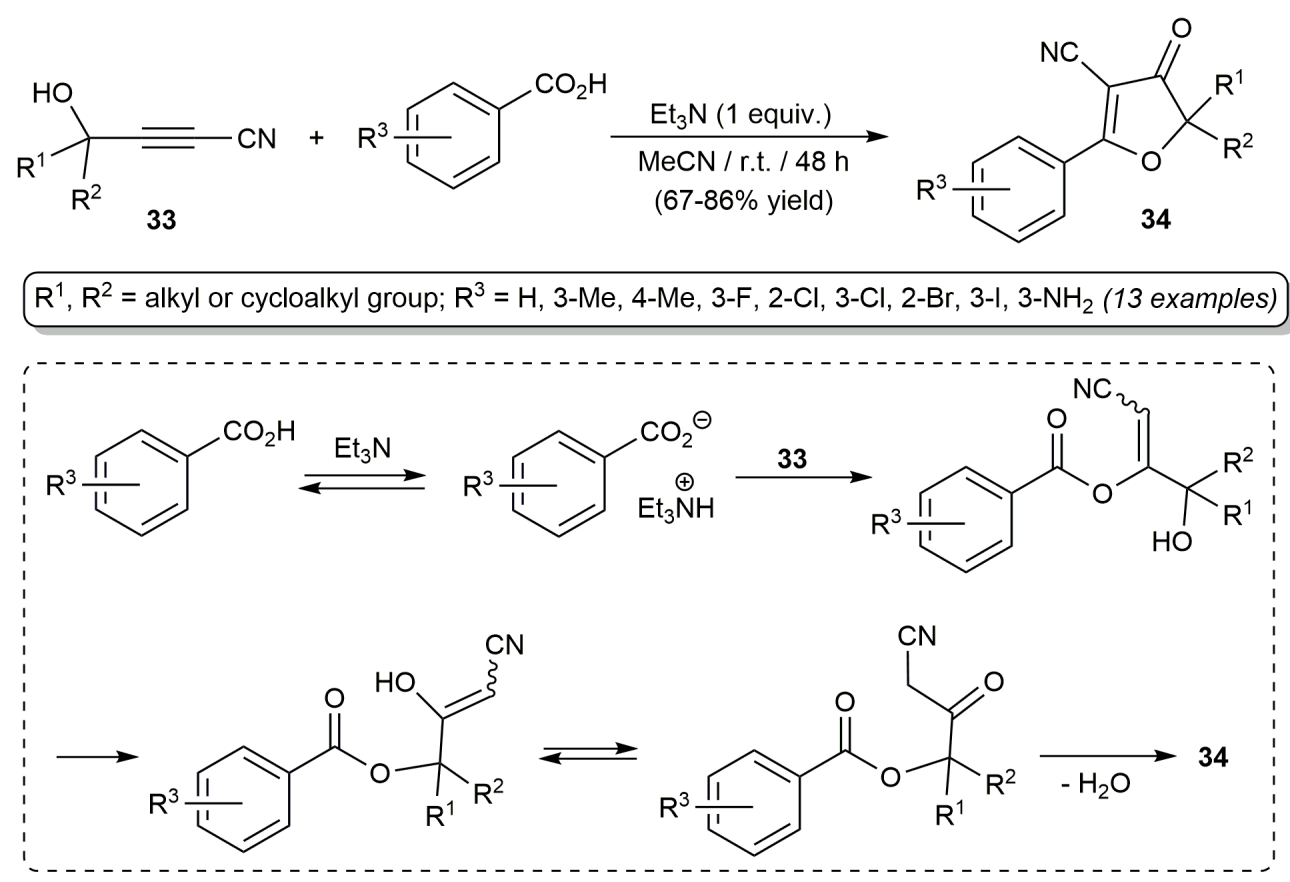

Scheme 18. Access to 4-cyano-3(2H)-furanones 34 from cyanopropargylic alcohols 33. 
Related tandem reactions involving naphthoic acids, ${ }^{108}$ furan and benzofuran carboxylic acids, ${ }^{109}$ thiophene and benzothiophene carboxylic acids, ${ }^{110}$ and pyrrole and indole carboxylic acids, ${ }^{111}$ were also described by Trofimov and co-workers, giving access to a large variety of functionalized $3(2 \mathrm{H})$-furanones. However, we must note that longer reaction times or the use microwave irradiation $\left(100{ }^{\circ} \mathrm{C}\right)$ were in these cases required to generate the products in good yields. On the other hand, starting from 2-hydroxybenzoic acid, compounds 35 (see Figure 4), incorporating two molecules of the cyanopropargylic alcohols 33, were selectively formed irrespective of the stoichiometry employed in the reaction. ${ }^{112}$ These compunds result from the nucleophilic addition of the hydroxyl group of the initially formed 4-cyano-3(2H)-furanones 34 to the carbon-carbon triple bond of the second molecule of the cyanopropargylic alcohol. Also of note is the fact that, although in most cases the reactions proceed with exquisite chemoselectivity, formation of trace amounts of the 2,3-dihydrofurans 36 (see Figure 4) was in some cases observed. In a very recent study, Trofimov and co-workers demonstrated that the formation of these 2:1 adducts is favoured when the reactions are performed with an excess of the alkynes 33, a substoichiometric amount of Et ${ }_{3} \mathrm{~N}$, or when bulky substituents are present in the carboxylic acids $\mathrm{R}^{3} \mathrm{CO}_{2} \mathrm{H}$ employed. ${ }^{113}$

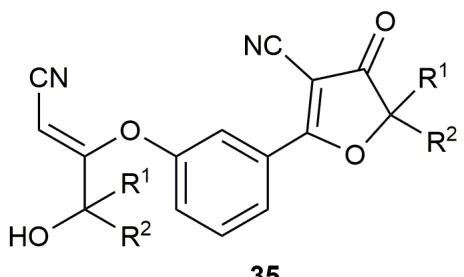

35

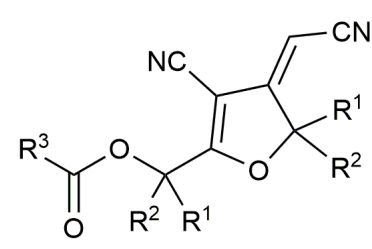

36

Figure 4. Structures of compounds 35 and 36.

Furthermore, the addition of carboxylic acids to aromatic and heteroaromatic ynals $\mathbf{3 7}$ catalyzed by the diaryl prolinol TMS ether 38 has also been described (Scheme 19). ${ }^{114}$ This organocatalytic process allowed the synthesis of a large variety of disubstituted enol esters 39 through an unprecedented amine-catalyzed conjugate addition/rearrangement sequence. Interestingly, the reactions procedeed with very high regio- and stereoselectivity. In particular, simply by controlling the reaction temperature, it was possible to obtain the enol esters 39 as the corresponding $Z$ ( $Z$ selectivity $\geq 94 \%$ at $0{ }^{\circ} \mathrm{C}$ ) or $E$ isomers ( $E$ selectivity $\geq 94 \%$ at $30{ }^{\circ} \mathrm{C}$ ). Mechanistic studies suggested that isomerizarion of the kinetic $Z$ products into the thermodinamically more stable $E$ ones is and acid promoted process, which is favoured by the temperature. Also of note is the fact that the mild reactions conditions employed allowed the use of a broad array of densely functionalized ynals and caboxylic acids, including examples of biological and pharmacological interest such as retinoic acid, mycophenolic acid, ibuprofen or flurbiprofen, among others. The only limitation encoutered by the authors was the use of aliphatic carboxylic acids, which showed a much lower reactivity compared to the aromatic ones and led to mixtures of products.

Finally, we must also indicate that the hydro-oxycarbonylation of alkynes with trifluoroacetic acid catalyzed by 10 mol\% of $B\left(C_{6} F_{5}\right)_{3}$ has been recently reported. ${ }^{115}$ However, the scope of the process was not explored in much detail. In particular, only one internal alkyne, i.e. diphenylacetylene, was employed, leading to the corresponding trisubstituted enol ester $(Z)-\mathrm{PhCH}=\mathrm{CPh}\left(\mathrm{OCOCF}_{3}\right)$ in $70 \%$ yield. 


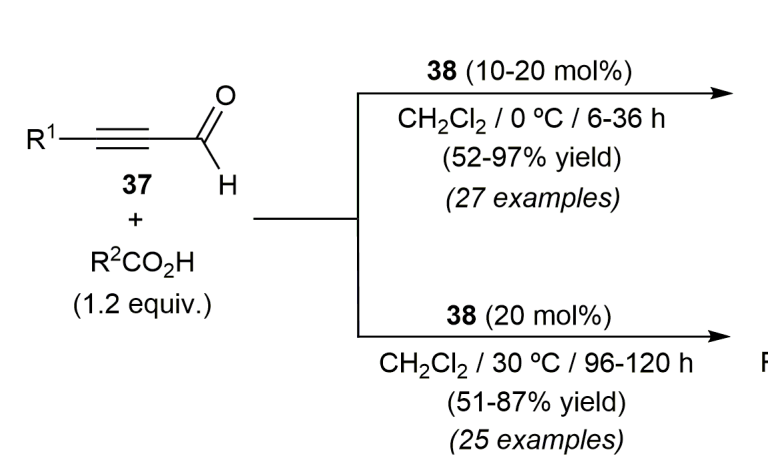<smiles>[R]C(=O)/C=C\OC([R])[R19]</smiles>

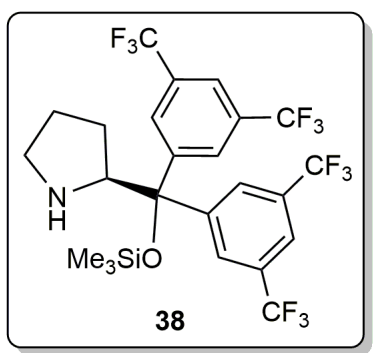

(51-87\% yield)

(E)-39

$\mathrm{R}^{1}=$ alkyl, aryl or heteroaryl group; $\mathrm{R}^{2}=$ aryl, heteroaryl or alkenyl group<smiles>[R]C(=O)/C=C\OC([R])=O</smiles>

(Z)-39

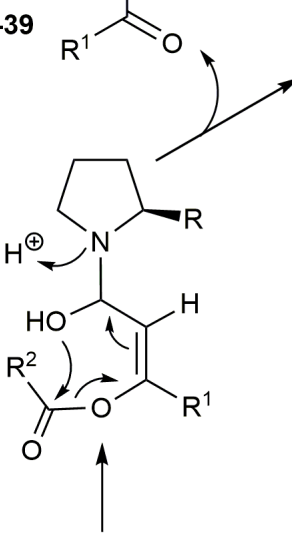<smiles>[R]C1CCCN1</smiles><smiles>[R]C#CC=O</smiles>
38<smiles>[R]CC#C/C=C(\CCO)N1CCC[C@H]1[R]</smiles><smiles>[R]C(=O)O/C([R])=C\C(O)N1CCCC1[R]</smiles><smiles>[13CH3]</smiles><smiles>[3H][3H]</smiles>

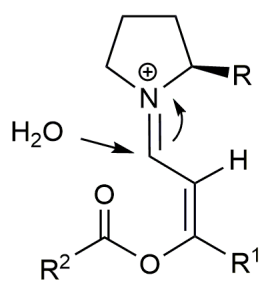<smiles>[R]C(=O)OCC=CC(C)=O</smiles>
(Z)-39<smiles>[R]C(=O)/C=C/OC([R])=O</smiles>

Scheme 19. Amine-catalyzed conjugate addition/rearrangement reaction of ynals with carboxylic acids.

\section{Conclusions}

Known since the 1980s, the intermolecular catalytic addition of carboxylic acids to alkynes has become one of the most powerful tools to synthesize useful enol esters in an atom economical manner. However, for a long time, the involvement of internal alkynes in these reactions has been considered problematic given their intrinsic lower reactivity in comparison with their terminal counterparts. This fact has made that the vast majority of studies in the field have focused on the latter. Throughout this review article we have presented in 
detail all the examples described in the literature in which internal alkynes have been subjected to a hydrooxycarbonylation reaction. The most recent results clearly demonstrate that it is possible to perform these reactions with good a regio- and stereocontrol just by selecting appropriate activating/directing substituents on the $\mathrm{C} \equiv \mathrm{C}$ bond, or by using highly reactive transition metal catalysts, thus opening new synthetic routes for the selective preparation of trisubstituted enol esters.

\section{Acknowledgements}

The authors acknowledge the Spanish MINECO (projects CTQ2013-40591-P and CTQ2016-75986-P) and the Gobierno del Principado de Asturias (project GRUPIN14-006) for financial support. J. F. thanks MINECO and ESF for the award of a Juan de la Cierva contract.

\section{References}

1 Bruneau, C.; Neveux, M.; Zabouche, Z.; Ruppin, C.; Dixneuf, P. H. Synlett 1991, 755-763.

http://dx.doi.org/10.1055/s-1991-20866

2 Bosco, J. W. J.; Saikia, A. K. Chem. Commun. 2004, 1116-1117.

http://dx.doi.org/10.1039/b401218f

3 Magens, S.; Ertelt, M.; Jatsch, A.; Plietker, B. Org. Lett. 2008, 10, 53-56.

http://dx.doi.org/10.1021/ol702580a

4 Kumar, M.; Bagchi, S.; Sharma, A. New J. Chem. 2015, 39, 8329-8336.

http://dx.doi.org/10.1039/c5nj01436k

5 Ito, H.; Ueda, M. Macromolecules 1990, 23, 2885-2894.

http://dx.doi.org/10.1021/ma00213a012

6 Liu, X.; Coutelier, O.; Harrisson, S.; Tassaing, T.; Marty, J.-D.; Destarac, M. ACS Macro Lett. 2015, 4, 89-93. http://dx.doi.org/10.1021/mz500731p

7 Foarta, F.; Landis, C. R. J. Org. Chem. 2016, 81, 11250-11255.

http://dx.doi.org/10.1021/acs.joc.6b02210

8 Jena, R. K.; Das, U. K.; Ghorai, A.; Bhattacharjee, M. Eur. J. Org. Chem. 2016, 6015-6021. http://dx.doi.org/10.1002/ejoc.201601091

9 Mamone, P.; Grünberg, M. F.; Fromm, A.; Khan, B. A.; Gooßen, L. J. Org. Lett. 2012, 14, 3716-3719. http://dx.doi.org/10.1021/ol301563g

10 Konrad, T. M.; Schmitz, P.; Leitner, W.; Franciò, G. Chem. Eur. J. 2013, 19, 13299-13303. http://dx.doi.org/10.1002/chem.201303066

11 Kleman, P.; González-Liste, P. J.; García-Garrido, S. E.; Cadierno, V.; Pizzano, A. Chem. Eur. J. 2013, 19, 13299-13303.

http://dx.doi.org/10.1002/chem.201303500

12 Kleman, P.; González-Liste, P. J.; García-Garrido, S. E.; Cadierno, V.; Pizzano, A. ACS Catal. 2014, 4, 43984408.

http://dx.doi.org/10.1021/cs501402z

13 Bonnarme, V.; Bachmann, C.; Cousson, A.; Mondon, M.; Gesson, J.-P. Tetrahedron 1999, 55, $433-448$.

http://dx.doi.org/10.1016/S0040-4020(98)01041-2 
14 Hara, H.; Hirano, M.; Tanaka, K. Org. Lett. 2008, 10, 2537-2540.

http://dx.doi.org/10.1021/ol800813g

15 Kumar, M.; Bagchi, S.; Sharma, A. RSC Adv. 2015, 5, 53592-53603.

http://dx.doi.org/10.1039/c5ra10073a

16 Masutomi, K.; Sugiyama, H.; Uekusa, H.; Shibata, Y.; Tanaka, K. Angew. Chem. Int. Ed. 2016, 55, 1537315376.

http://dx.doi.org/10.1002/anie.201608952

17 Urabe, H.; Suzuki, D.; Sasaki, M.; Sato, F. J. Am. Chem. Soc. 2003, 125, 4036-4037.

http://dx.doi.org/10.1021/ja034369a

18 Candish, L.; Lupton, D. W. Org. Biomol. Chem. 2011, 9, 8182-8189.

http://dx.doi.org/10.1039/c1ob05953j

19 Yin, Z.; Liu, Z.; Huang, Z.; Chu, Y.; Chu, Z.; Hu, J.; Gao, L.; Song, Z. Org. Lett. 2015, 17, 1553-1556. http://dx.doi.org/10.1021/acs.orglett.5b00437

20 Panda, N.; Mishra, P.; Mattan, I. J. Org. Chem. 2016, 81, 1047-1056.

http://dx.doi.org/10.1021/acs.joc.5b02602

21 Abrams, M. L.; Foarta, F.; Landis, C. R. J. Am. Chem. Soc. 2014, 136, 14583-14588.

http://dx.doi.org/10.1021/ja507701k

22 Holthusen, K.; Leitner, W.; Franciò, G. J. Org. Chem. 2016, 81, 4823-4828.

http://dx.doi.org/10.1021/acs.joc.5b02851

23 Schmitz, C.; Holthusen, K.; Leitner, W.; Franciò, G. ACS Catal. 2016, 6, 1584-1589.

http://dx.doi.org/10.1021/acscatal.5b02846

24 Takeno, M.; Kikuchi, S.; Morita, K.-I.; Nishiyama, Y.; Ishii, Y. J. Org. Chem. 1995, 60, 4974-4975. http://dx.doi.org/10.1021/jo00121a008

25 Gooßen, L. J.; Paetzold, J. Angew. Chem. Int. Ed. 2004, 43, 1095-1098.

http://dx.doi.org/10.1002/anie.200352357

26 Geibel, I.; Christoffers, J. Eur. J. Org. Chem. 2016, 918-920.

http://dx.doi.org/10.1002/ejoc.201600057

27 Geibel, I.; Dierks, A.; Schmidtmann, M.; Christoffers, J. J. Org. Chem. 2016, 81, 7790-7798. http://dx.doi.org/10.1021/acs.joc.6b01441

28 Martz, J. T.; Gokel, G. W.; Olofson, R. A. Tetrahedron Lett. 1979, 20, 1473-1476. http://dx.doi.org/10.1016/S0040-4039(01)86181-5

29 Kinoshita, H.; Hori, I.; Oishi, T.; Ban, Y. Chem. Lett. 1984, 13, 1517-1520.

http://dx.doi.org/10.1246/cl.1984.1517

30 Chen, X.; Li, X.; Song, H.; Qian, Y.; Wang, F. Tetrahedron Lett. 2011, 52, 3588-3591. http://dx.doi.org/10.1016/j.tetlet.2011.04.117

31 Onishi, Y.; Yoneda, Y.; Nishimoto, Y.; Yasuda, M.; Baba, A. Org. Lett. 2012, 14, 5788-5791. http://dx.doi.org/10.1021/ol302888k

32 Masuyama, Y.; Sakai, T.; Kato, T.; Kurusu, Y. Bull. Chem. Soc. Jpn. 1994, 67, 2265-2272. http://dx.doi.org/10.1246/bcsj.67.2265

33 Dang, H.-S.; Roberts, B. P. Chem. Commun. 1996, 2201-2202. http://dx.doi.org/10.1039/cc9960002201

34 Yanagisawa, M.; Shimamura, T.; lida, D.; Matsuo, J.; Mukaiyama, T. Chem. Pharm. Bull. 2000, 48, 18381840.

http://dx.doi.org/10.1248/cpb.48.1838 
35 Isambert, N.; Cruz, M.; Arévalo, M. J.; Gómez, E.; Lavilla, R. Org. Lett. 2007, 9, 4199-4202. http://dx.doi.org/10.1021/ol701717z

36 Krause, T.; Baader, S.; Erb, B.; Gooßen, L. J. Nat. Commun. 2016, 7, 11732. http://dx.doi.org/10.1038/ncomms11732

37 Dai, J.; Sorribas, A.; Yoshida, W. Y.; Williams, P. G. Phytochemistry 2010, 71, 2168-2173. http://dx.doi.org/10.1016/i.phytochem.2010.09.008

38 Hartkoorn, R. C.; Sala, C.; Neres, J.; Pojer, F.; Magnet, S.; Mukherjee, R.; Uplekar, S.; Boy-Röttger, S.; Altmann, K.-H.; Cole, S. T. EMBO Mol. Med. 2012, 4, 1032-1042.

http://dx.doi.org/10.1002/emmm.201201689

39 Wang, G. C.; Li, T.; Deng, F.-Y.; Li, Y.-L.; Ye, W.-C. Bioorg. Med. Chem. Lett. 2013, 23, 1379-1382. http://dx.doi.org/10.1016/j.bmcl.2012.12.077

40 Rasher, D. B.; Stout, E. P.; Engel, S.; Shearer, T. L.; Kubanek, J.; Hay, M. E. Proc. Natl. Acad. Sci. U.S.A. 2015, 112, 12110-12115.

http://dx.doi.org/10.1073/pnas.1508133112

41 Smith, M. B.; March, J. Advanced Organic Chemistry, $5^{\text {th }}$ ed.; John Wiley \& Sons, New York, 2001, p. 486.

42 Larock, R. C.; Leong, W. W. In Comprehensive Organic Synthesis; Trost, B. M., Fleming I., Eds.; Pergamon Press, Oxford, 1991, vol. 4, pp. 269-327.

http://dx.doi.org/10.1016/B978-0-08-052349-1.00096-2

43 Huang, F.; Quach, T. D.; Batey, R. A. Org. Lett. 2013, 15, 3150-3153.

http://dx.doi.org/10.1021/ol4013712

44 Yoo, W.-J.; Li, C.-J. J. Org. Chem. 2006, 71, 6266-6268.

http://dx.doi.org/10.1021/jo0606103

45 Park, J.; Han, S. H.; Sharma, S.; Han, S.; Shin, Y.; Mishra, N. K.; Kwak, J. H.; Lee, C. H.; Lee, J.; Kim, I. S. J. Org. Chem. 2014, 79, 4735-4742.

http://dx.doi.org/10.1021/jo500576x

46 Henderson, W. H.; Check, C. T.; Proust, N.; Stambuli, J. P. Org. Lett. 2010, 12, 824-827. http://dx.doi.org/10.1021/ol902905w

47 Yang, D.; Ding, S.; Huang, J.; Zhao, K. Chem. Commun. 2013, 49, 1211-1213. http://dx.doi.org/10.1039/c2cc37779a

48 Liang, D.; Wang, M.; Dong, Y.; Guo, Y.; Liu, Q. RSC Adv. 2014, 4, 6564-6567. http://dx.doi.org/10.1039/c3ra47282e

49 Wang, S.; Zhang, L. Org. Lett. 2006, 8, 4585-4587. http://dx.doi.org/10.1021/ol0618151

50 Peng, Y.; Cui, L.; Zhang, G.; Zhang, L. J. Am. Chem. Soc. 2009, 131, 5062-5063. http://dx.doi.org/10.1021/ja901048w

51 Schaefer, C.; Fu, G. C. Angew. Chem. Int. Ed. 2005, 44, 4606-4608. http://dx.doi.org/10.1002/anie.200501434

52 Alonso, F; Beletskaya, I. P.; Yus, M. Chem. Rev. 2004, 104, 3079-3160. http://dx.doi.org/10.1021/cr0201068

53 Beller, M.; Seayard, J.; Tillack, A.; Jiao, H. Angew. Chem. Int. Ed. 2004, 43, 3368-3398. http://dx.doi.org/10.1002/anie.200300616

54 Gooßen, L. J.; Rodríguez, N.; Gooßen, K. Angew. Chem. Int. Ed. 2008, 47, 3100-3120. http://dx.doi.org/10.1002/anie.200704782 
55 Gooßen, L. J.; Gooßen, K.; Rodríguez, N.; Blanchot, M.; Linder, C.; Zimmermann, B. Pure Appl. Chem. 2008, 80, 1725-1733.

http://dx.doi.org/10.1351/pac200880081725

56 Hintermann, L. Top. Organomet. Chem. 2010, 31, 123-155.

http://dx.doi.org/10.1007/978-3-642-12073-2 6

57 Rotem, M.; Shvo, Y. Organometallics 1983, 2, 1689-1691.

http://dx.doi.org/10.1021/om50005a037

58 Tomás-Mendivil, E.; Toullec, P. Y.; Díez, J.; Conejero, S.; Michelet, V.; Cadierno, V. Org. Lett. 2012, 14, 2520-2523.

http://dx.doi.org/10.1021/ol300811e

59 Tomás-Mendivil, E.; Toullec, P. Y.; Borge, J.; Conejero, S.; Michelet, V.; Cadierno, V. ACS Catal. 2013, 3, 3086-3098.

http://dx.doi.org/10.1021/cs4009144

60 Espinosa-Jalapa, N. A.; Ke, D.; Nebra, N.; Le Goanvic, L.; Mallet-Ladeira, S.; Monot, J.; Martín-Vaca, B.; Bourissou, D. ACS Catal. 2014, 4, 3605-3611.

http://dx.doi.org/10.1021/cs5010322

61 Eriksson, K.; Verho, O.; Nylholm, L.; Oscarsson, S.; Bäckvall, J.-E. Eur. J. Org. Chem. 2015, 2250-2255. http://dx.doi.org/10.1002/ejoc.201403664

62 Monot, J.; Brunel, P.; Kefalidis, C. E.; Espinosa-Jalapa, N. A.; Maron L.; Martín-Vaca, B.; Bourissou, D. Chem. Sci. 2016, 7, 2179-2187.

http://dx.doi.org/10.1039/c5sc04232a

63 Conde, N.; San Martin, R.; Herrero, M. T.; Domínguez, E. Adv. Synth. Catal. 2016, 358, 3283-3292. http://dx.doi.org/10.1002/adsc.201600492

64 Patil, N. T.; Kavthe, R. D.; Shinde, V. S. Tetrahedron 2012, 68, 8079-8146.

http://dx.doi.org/10.1016/i.tet.2012.05.125

65 Bruneau, C. Top. Organomet. Chem. 2013, 43, 203-230.

http://dx.doi.org/10.1007/3418 201117

66 Dixneuf, P. H. Catal. Lett. 2015, 145, 360-372.

http://dx.doi.org/10.1007/S10562-014-1444-9

67 Rotem, M.; Shvo, Y. J. Organomet. Chem. 1993, 448, 189-204.

http://dx.doi.org/10.1016/0022-328X(93)80084-O

68 Kawatsura, M.; Namioka, J.; Kajita, K.; Yamamoto, M.; Tsuji, H.; Itoh, T. Org. Lett. 2011, 13, 3285-3287. http://dx.doi.org/10.1021/ol201238u

69 Ruppin, C.; Dixneuf, P. H. Tetrahedron Lett. 1986, 27, 6323-6324. http://dx.doi.org/10.1016/S0040-4039(00)87798-9

70 Kabouche, A.; Kabouche, Z.; Bruneau, C.; Dixneuf, P. H. J. Soc. Alger. Chim. 1999, 9, 141-148.

71 Karabulut, S.; Öztürk, B. Ö.; İmamoğlu, Y. J. Organomet. Chem. 2010, 695, 2161-2166. http://dx.doi.org/10.1016/j.jorganchem.2010.05.018

72 Jeschke, J.; Gäbler, C.; Lang, H. J. Org. Chem. 2016, 81, 476-484. http://dx.doi.org/10.1021/acs.joc.5b02293

73 Jeschke, J.; Engelhardt, T. B.; Lang, H. Eur. J. Org. Chem. 2016, 1548-1554.

http://dx.doi.org/10.1002/ejoc.201501583

74 Lu, X.; Zhu, G.; Ma, S. Tetrahedron Lett. 1992, 33, 7205-7206.

http://dx.doi.org/10.1016/S0040-4039(00)60873-0 
75 Wakabayashi, T.; Ishii, Y.; Murata, T.; Mizobe, Y.; Hidai, M. Tetrahedron Lett. 1995, 36, 5585-5588. http://dx.doi.org/10.1016/0040-4039(95)01067-R

76 Smith, D. L.; Goundry, W. R. F.; Lam, H. W. Chem. Commun. 2012, 48, 1505-1507. http://dx.doi.org/10.1039/c1cc13595c

77 Zificsak, C. A.; Mulder, J. A.; Hsung, R. P.; Rameshkumar, C.; Wei, L.-L. Tetrahedron 2001, 57, 7575-7606. http://dx.doi.org/10.1016/S0040-4020(01)00681-0

78 G. Evano, A. Coste, K. Jouvin, Angew. Chem. Int. Ed. 2010, 49, 2840-2859. http://dx.doi.org/10.1002/anie.200905817

79 DeKorver, K. A.; Li, H.; Lohse, A. G.; Hayashi, R.; Lu. Z.; Zhang, Y.; Hsung, R. P. Chem. Rev. 2010, 110, 50645106.

http://dx.doi.org/10.1021/cr100003s

80 Tsukada, N.; Takahashi, A.; Inoue, Y. Tetrahedron Lett. 2011, 52, 248-250. http://dx.doi.org/10.1016/i.tetlet.2010.11.046

81 Wu, J.; Deng, X.; Hirao, H.; Yoshikai, N. J. Am. Chem. Soc. 2016, 138, 9105-9108. http://dx.doi.org/10.1021/jacs.6b06247

82 Fang, G.; Bi, X. Chem. Soc. Rev. 2015, 44, 8124-8173. http://dx.doi.org/10.1039/c5cs00027k

83 Ishino, Y.; Nishiguchi, I.; Nakao, S.; Hirashima, T. Chem. Lett. 1981, 10, 641-644. http://dx.doi.org/10.1246/cl.1981.641

84 Yin, J.; Bai, Y.; Mao, M.; Zhu, G. J. Org. Chem. 2014, 79, 9179-9185. http://dx.doi.org/10.1021/jo501615a

85 Modern Gold Catalyzed Synthesis; Hashmi, A. S. K., Toste, F. D., Eds.; Wiley-VCH, Weinheim, 2012.

86 Gold Catalysis: An Homogeneous Approach; Toste, F. D., Michelet, V., Eds.; Imperial College Press, London, 2014.

87 Roembke, P.; Schmidbaur, H.; Cronje, S.; Raubenheimer, H. J. Mol. Catal. A: Chem. 2004, 212, 35-42. http://dx.doi.org/10.1016/i.molcata.2003.11.011

88 Chary, B. C.; Kim, S. J. Org. Chem. 2010, 75, 7928-7931.

http://dx.doi.org/10.1021/jo101543q

89 González-Liste, P. J.; León, F.; Arribas, I.; Rubio, M.; García-Garrido, S. E.; Cadierno, V.; Pizzano, A. ACS Catal. 2016, 6, 3056-3060.

http://dx.doi.org/10.1021/acscatal.6b00282

90 González-Liste, P. J.; Francos, J.; García-Garrido, S. E.; Cadierno, V. J. Org. Chem. 2017, 82, 1507-1516. http://dx.doi.org/10.1021/acs.joc.6b02712

91 Wu, W.; Jiang, H. Acc. Chem. Res. 2014, 47, 2483-2504. http://dx.doi.org/10.1021/ar5001499

92 León, F.; González-Liste, P. J.; García-Garrido, S. E.; Arribas, I.; Rubio, M.; Cadierno, V.; Pizzano, A. J. Org. Chem. 2017, 82, 5852-5867. http://dx.doi.org/10.1021/acs.joc.7b00710

93 González-Liste, P. J.; García-Garrido, S. E.; Cadierno, V. Org. Biomol. Chem. 2017, 15, 1670-1679. http://dx.doi.org/10.1039/c6ob02800d

94 Cadierno, V.; Francos, J.; Gimeno, J. Organometallics 2011, 30, 852-862. http://dx.doi.org/10.1021/om1010325

95 Wang, Y.; Wang, Z.; Li, Y.; Wu, G.; Cao, Z.; Zhang, L. Nat. Commun. 2014, 5, 3470. http://dx.doi.org/10.1038/ncomms4470 
96 Dupuy, S.; Gasperini, D.; Nolan, S. P. ACS Catal. 2015, 5, 6918-6921.

http://dx.doi.org/10.1021/acscatal.5b02090

97 Xu, S.; Liu, J.; Hu, D.; Bi, X. Green Chem. 2015, 17, 184-187.

http://dx.doi.org/10.1039/c4gc01328j

98 Cook, A. M.; Wolf, C. Angew. Chem. Int. Ed. 2016, 55, 2929-2933.

http://dx.doi.org/10.1002/anie.201510910

99 Hu, L.; Xu, S.; Zhao, Z.; Yang, Y.; Peng, Z.; Yang, M.; Wang, C.; Zhao, J. J. Am. Chem. Soc. 2016, 138, 1313513138.

http://dx.doi.org/10.1021/jacs.6b07230

100 Pirwerdjan, R.; Priebbenow, D. L.; Becker, P.; Lamers, P.; Bolm, C. Org. Lett. 2013, 15, 5397-5399.

http://dx.doi.org/10.1021/ol4026028

101 Priebbenow, D. L.; Becker, P.; Bolm, C. Org. Lett. 2013, 15, 6155-6157.

http://dx.doi.org/10.1021/ol403106e

102 Pirwerdjan, R.; Becker, P.; Bolm, C. Org. Lett. 2015, 17, 5008-5011.

http://dx.doi.org/10.1021/acs.orglett.5b02477

103 Pirwerdjan, R.; Becker, P.; Bolm, C. Org. Lett. 2016, 18, 3307-3309.

http://dx.doi.org/10.1021/acs.orglett.6b01646

104 Perrin, F. G.; Kiefer, G.; Jeanbourquin, L.; Racine, S.; Perrotta, D.; Waser, J.; Scopelliti, R.; Severin, K. Angew. Chem. Int. Ed. 2015, 54, 13393-13396.

http://dx.doi.org/10.1002/anie.201507033

105 Fan, M. J.; Li, G.-Q.; Liang, Y.-M. Tetrahedron 2006, 62, 6782-6791.

http://dx.doi.org/10.1016/i.tet.2006.04.100

106 Trofimov, B. A.; Shemyakina, O. A.; Mal'kina, A. G.; Ushakov, I. A.; Kazheva, O. N.; Alexandrov, G. G.; Dyachenko, O. A. Org. Lett. 2010, 12, 3200-3203.

http://dx.doi.org/10.1021/ol1011532

107 Shemyakina, O. A.; Mal’kina, A. G.; Nosyreva, V. V.; Ushakov, I. A.; Trofimov, B. A. Arkivoc 2012 (viii) 319325.

http://dx.doi.org/10.3998/ark.5550190.0013.827

108 Mal'kina, A. G.; Volostnykh, O. G.; Petrushenko, K. B.; Shemyakina, O. A.; Nosyreva, V. V.; Ushakov, I. A.; Trofimov, B. A. Tetrahedron 2013, 69, 3714-3720.

http://dx.doi.org/10.1016/j.tet.2013.03.007

109 Trofimov, B. A.; Stepanov, A. V.; Mal'kina, A. G.; Volostnykh, O. G.; Shemyakina, O. A.; Ushakov, I. A.; Synth. Commun. 2015, 45, 2718-2729.

http://dx.doi.org/10.1080/00397911.2015.1103872

110 Mal'kina, A. G.; Volostnykh, O. G.; Stepanov, A. V.; Ushakov, I. A.; Petrushenko, K. B.; Trofimov, B. A. Synthesis 2013, 45, 3435-3441.

http://dx.doi.org/10.1055/s-0033-1340009

111 Mal'kina, A. G.; Shemyakina, O. A.; Stepanov, A. V.; Volostnykh, O. G.; Ushakov, I. A.; Sobenina, L. N.; Borodina, T. N.; Smirnov, V. I.; Trofimov, B. A. Synthesis 2016, 48, 271-280.

http://dx.doi.org/10.1055/s-0035-1560754

112 Shemyakina, O. A.; Stepanov, A. V.; Volostnykh, O. G.; Mal'kina, A. G.; Ushakov, I. A.; Trofimov, B. A. Russ. J. Org. Chem. 2014, 50, 1617-1620.

http://dx.doi.org/10.1134/S107042801411013X 
113 Mal'kina, A. G.; Stepanov, A. V.; Sobenina, L. N.; Shemyakina, O. A.; Ushakov, I. A.; Smirnov, V. I.; Trofimov, B. A. Synthesis 2016, 48, 1880-1891. http://dx.doi.org/10.1055/s-0035-1561591

114 Huang, H.; Zhang, X.; Yu, C.; Li, X.; Zhang, Y.; Wang, W. ACS Catal. 2016, 6, 8030-8035. http://dx.doi.org/10.1021/acscatal.6b02206

115 Wen, Z.; Tian, C.; Borzov, M. V.; Nie, W. Acta Chim. Sinica 2016, 74, 498-502. http://dx.doi.org/10.6023/A16040164 